Florida International University

FIU Digital Commons

FIU Electronic Theses and Dissertations

University Graduate School

$11-15-2013$

\title{
Accepting the Failure of Human and State Bodies: Interactions of Syphilis and Space in "Hamlet" and "The Knight of the Burning Pestle"
}

Laura E. Radford

lradf001@fiu.edu

DOI: $10.25148 /$ etd.FI13121214

Follow this and additional works at: https:// digitalcommons.fiu.edu/etd

Part of the Literature in English, Anglophone outside British Isles and North America Commons, Literature in English, British Isles Commons, and the Modern Literature Commons

\section{Recommended Citation}

Radford, Laura E., "Accepting the Failure of Human and State Bodies: Interactions of Syphilis and Space in "Hamlet" and "The Knight of the Burning Pestle"'" (2013). FIU Electronic Theses and Dissertations. 1034.

https://digitalcommons.fiu.edu/etd/1034 


\title{
FLORIDA INTERNATIONAL UNIVERSITY
}

Miami, Florida

ACCEPTING THE FAILURE OF HUMAN AND STATE BODIES: INTERACTIONS OF SYPHILIS AND SPACE IN “HAMLET” AND “THE KNIGHT OF THE BURNING PESTLE”

\author{
A thesis submitted in partial fulfillment of the \\ requirements for the degree of \\ MASTER OF ARTS \\ in \\ ENGLISH \\ by \\ Laura E. Radford
}


To: Dean Kenneth G. Furton

College of Arts and Sciences

This thesis, written by Laura E. Radford, and entitled Accepting the Failure of Human and State Bodies: Interactions of Syphilis and Space in "Hamlet" and "The Knight of the Burning Pestle", having been approved in respect to style and intellectual content, is referred to you for judgment.

We have read this thesis and recommend that it be approved.

$\begin{array}{r}\hline \text { Vernon Dickson } \\ \hline \text { Jason Pearl } \\ \hline \text { James Sutton, Major Professor }\end{array}$

Date of Defense: November 142013

The thesis of Laura E. Radford is approved.

\begin{tabular}{r} 
Dean Kenneth G. Furton \\
College of Arts and Sciences \\
\hline Dean Lakshmi N. Reddi \\
University Graduate School
\end{tabular}

Florida International University, 2013 


\section{DEDICATION}

I dedicate this thesis to my family and friends, and of course, el Chapulin - all of whom have both fostered and supported my research and writing over the past few years in various different ways. You all show that at each and every turn, life is truly abundant. 


\section{ACKNOWLEDGMENTS}

I would like to thank the members of my committee for the extraordinary amount of effort, patience, creativity, and humor they put into this project. I'd particularly like to thank Dr. Dickson for introducing me to "The Knight of the Burning Pestle" in the first place; without him, I surely would not have added this play to my study of "Hamlet;" in addition, it was Dr. Pearl's preliminary notes which first steered me towards examining capital structures in "The Knight of the Burning Pestle," which became a major part of this analysis. Finally, I cannot fail to mention Dr. Sutton's overwhelming support of my ideas when they were little more than kernels; his encouragement of my often eccentric historical associations truly made me believe that this project was more than possible that it was good. 


\author{
ABSTRACT OF THE THESIS \\ ACCEPTING THE FAILURE OF HUMAN AND STATE BODIES: INTERACTIONS \\ OF SYPHILIS AND SPACE IN “HAMLET” AND “THE KNIGHT OF THE BURNING \\ PESTLE" \\ by \\ Laura E. Radford
}

Florida International University, 2013

Miami, Florida

Professor James Sutton, Major Professor

The purpose of this thesis is, first, to explore the presence and meaning of Foucault's heterotopia within William Shakespeare's "Hamlet” and Beaumont and Fletcher's "The Knight of the Burning Pestle." The heterotopia is a privileged space of self-reflection created by individuals or societies in crisis. In each play, the presence of crisis is explained though the metaphor of syphilis; to which individual characters respond by entering the reflective space of the heterotopia in order to countenance and "cure" their afflictions. The second purpose of this thesis is to examine the ways in which the crises acted upon the stage reflect pressing social anxieties of late - Elizabethan and earlyJacobean England: succession to the throne and shifting market structure. Both playwrights create heterotopic space for their audience through the structure of their dramatic work, and ask their audience to enter this reflective space, and consider -and learn from - their remarks upon the state of society. 


\section{TABLE OF CONTENTS}

CHAPTER

PAGE

I. Introduction: The Space of Syphilis in Early Modern England................1

II. "Hamlet:" A Sore Distraction..............................................12

III. "The Knight of the Burning Pestle:” A Merry Ghost, A Very Merry Ghost.46

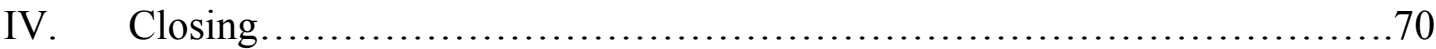

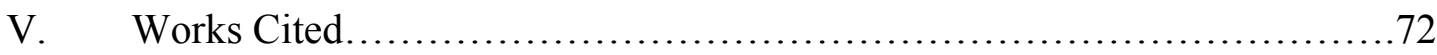




\section{INTRODUCTION}

The Space of Syphilis in Early Modern Drama

Edward W. Soja, in his spatio-theoretical discourse study Postmodern

Geographies: The Reassertion of Space in Critical Social Theory alleges that in the present day, "a distinctively postmodern and critical human geography is taking shape, brashly reasserting the interpretive significance of space in the historically privileged confines of contemporary critical thought" (11). For Soja, both our concepts and treatment of the wide expanse of the past is mired, somewhat vexingly, in the "alluring logic of historicism, the rational reduction of meaning and action to the temporal constitution and experience of social being" (14). That is, until very recently, our lives have been reflexively measured, to steal T.S Eliot's genre - transcendent metaphor, in the coffee spoons of eras and epochs, in the pacing of recorded events and historical progress; we have compared and privileged one generations triumphs over another's; and, perhaps most importantly, that who we are has been shaped purely by historical, temporal actions. For Soja, a "spatialization of thought and experience" has only relatively recently taken root within the collective theoretical consciousness, and considering the sheer volume of recent critical work focused upon experiences of space, one might be tempted to agree with his statements. While some theorists have noted a tendency to ignore more spatial forms of thinking, throughout the $18^{\text {th }}, 19^{\text {th }}$, and $20^{\text {th }}$ centuries those same theorists remarked with an almost alarming frequency upon the Middle Ages as remarkably spatially felt and constructed. For example, in Topophilia, Yi Fu Tuan illustrates how the prevalence of vertical, privileged Medieval physical structures, such as castle and cathedral towers, reflect a corresponding social and political space and shape; his ideas 
echoing the work of Gaston Bachelard, who had previously designated the tower as a primal image of verticality, illustrating a concurrent verticality in human power relations. In The Practice of Everyday Life, Michel de Certeau examines spaces of being within medieval maps, concluding that Dark Age reality was constructed upon a definitively spatial plane.

The mere existence of these sundry works illustrates the point that we have once again begun to think spatially - and the nearly obsessive focus upon the medieval seems to suggest that for this period of time, space may have been privileged over time. If space used to be felt before the modern era, and is starting to be felt now, in our post-modern epoch, there must have been a point at which it was replaced by a new way of organizing and constructing identity and difference. David Harvey delineates this idea in The Conditions of Post Modernity. In this work, he claims that this gradual act of spatial rejection took place throughout the Renaissance, which instituted major changes affecting both the production of space, and the way of seeing space more rationally and scientifically: artistic perspectivism, mathematical developments, objective and functional Ptolemaic mapping, and Newtonian optics. Simultaneously, focus shifted instead to time as timekeeping devices became more readily available and reliable. In his discussions of the domination of space by time, Harvey telegraphs from the $15^{\text {th }}$ Century Italian Renaissance to the industrial upheavals of the mid- $19^{\text {th }}$ Century, wholly omitting three hundred years of space, or as the majority might have it, of time - in particular, the change-filled early-Modern era, especially that of Northern Europe. How were space and time countered and encountered within those utterly transformative years? 
However, it seems to me far too vast a claim that Renaissance humanism, with its focus upon temporal progress alone, created such a blunt and sudden alteration in understanding. In general, I have found that within critical studies of space and human geography, much attention has been paid to a seeming preferential treatment of the temporal over the spatial, and of the purely temporal, and the purely spatial. Thus, I find that there is a critical silence regarding the imbrication of the temporal and spatial, and of their ability, or the possibility, of their coexistence and diachronic functionality. A plane upon which space and time coincide and work together is thus nonexistent; instead they are forever two elements constantly opposed and embattled, violently seeking to conquer the other. Eventually space and time flatten each other in a chaotic, cataclysmic event of “space-time compression," (Harvey) through which we become "respatialized," that is, accepting of these new modes of thinking space and time, and for the last few centuries, time has undoubtedly emerged victorious from this battle.

There is perhaps no other thinker so commonly associated with space, or another critic who has done more to open up the debate about space, place, and time as Michel Foucault. In a now- famous 1967 speech entitled "De Autres Espaces," Foucault describes the concept of heterotopia, or, spaces which create temporal-spatial unity and spaces and places which overlap, and slide both into and over one another. The heterotopia is, then, a space of imbrication - the location for a folding together of both time and space- those two qualities thought by so many to be utterly irreconcilable. For, in the articulation of heterotopia, Foucault gestures towards the possibility of a shared plane for time and space, wherein they work together in pursuit of a goal. Foucault 
describes the heterotopia as "privileged sacred or forbidden places, reserved for individuals in a state of crisis," which "create a space of illusion that exposes every real space, all the sites inside of which human life is partitioned, as still more illusory" (2). Heterotopia, then, in particular the heterotopia of crisis, might be a space created by either a single person or society, to which they can escape, or send those who are suffering through these crises, but also a space in which they are given the unique opportunity to examine the reality of their current state of being. Previous beliefs regarding reality are jettisoned when one encounters heterotopia - it is a place of unblinkered honesty. These are privileged, personal spaces: like a reflection within a mirror, they are real, but they are also non - existent, for they cannot be reached unless the circumstances are correct, and the cataclysmic event nigh and truly and physically felt. These crises, however, are real; for, above all, a heterotopia is a real space, because the human body, or in some cases the nation - the body politic- is an entity which is perpetually in crisis - it is only that a heterotopic space exposes that reality of crisis, instead of hiding or eluding it. It might be said that these supra-real spaces protect one in crisis, prepare one for the fruition of the coming cataclysmic event. Space and time cease moving, if just for a moment, and this lack of movement and progress allows for radical self and community discovery.

I believe that this imbrication of time and space, Foucault's heterotopia, can be viewed clearly within certain types of literature; most particularly, within the dramatic works of the Late Elizabethan and Jacobean stage - specifically William Shakespeare's Hamlet, and Francis Beaumont's The Knight of the Burning Pestle. This particular 
historical moment, distinctive for a number of reasons, witnessed the clash of space inherited from medieval forbears, with time, nascent in the growing politics of commerce, expansion of empire, and political regime change. These visible and felt instances of dramatic heterotopia are set -off by community disrupting events particular to early modern England; specifically, nascent political chaos caused by uncertain regime change, and emerging commercial structures: in other words, the anxiety surrounding the imminent death of Queen Elizabeth I, and the birth and subsequent rise of the modern commercial marketplace.

The end of Elizabeth I's reign, from the time of her triumph over the Spanish Armada in 1588 until her death in 1603, is sometimes called her second reign, so markedly different was it from the thirty years of prosperity and triumph following her 1556 accession. These final years were marked by political and economic uncertainty, not a small amount attributed to the fact that the ailing queen had no natural heir to take her place upon her passing. As Spenser's Gloriana aged, she furthermore made no explicit provision for a successor, fearing that she might encourage faction within her kingdom. Fearing the consequences of this lack of choice, in her very last years, her principal advisor Sir Robert Cecil began to groom James I of Scotland to take her position upon her imminent death. These details were not known by the British public they were kept most secret indeed. Lacking this important knowledge regarding their future, the British public was, as Elizabeth feared, thrown into turbulent factions, regardless of her demurral to name a successor. The air of political instability heightened as Elizabeth aged, and resulted in the creation and carrying out of several plots - for 
example, Essex's Rebellion (1601). This movement was easily able to drum up followers, which points indubitably to a growing fear of what would happen after Elizabeth I died.

If the mainly stable rule of Elizabeth I had established relative complacency within the masses, so too had traditional commercial structures. An adherence to feudalistic structures had persisted until the reign of Henry VII, when a large-scale campaign to colonize Ireland, both by physical and monetary force, was affected. These events marked the beginning of a definite trend towards what we now call capitalism - a trend which, in England, only sped up throughout the remainder of the $16^{\text {th }}$ century and into the beginnings of the $17^{\text {th }}$, bolstered by the discovery and later colonization of the North American colonies (Meiksins- Wood). The departure from traditional, comfortable commercial models provoked anxiety within all classes of the British public, rich and poor alike. A new focus upon foreign trade and merchants, and the creation of a new, prominent social class upset traditional views regarding who was, and who was not valuable to society. A new community was created, and as a result, a number of longstanding communities were disrupted.

However, I have found that within both Hamlet and The Knight of the Burning Pestle, the community disrupting events I outline above are not described within their own "space": that is, the playwrights do not counter these pressing societal issues headon. I believe this is because, quite simply, they could not be countered head-on. Because of their magnitude and sheer novelty, they had to be described and filtered of necessity through a language and logic which would have been both readily and metaphorically 
understood at the time. But what terminology would have made sense to an entire population at this historical juncture, and would have created an appropriate sieve through which anxieties could be sifted? I posit that the venereal infection syphilis, which was a major concern for English society throughout the $16^{\text {th }}$ and $17^{\text {th }}$ centuries, provided the perfect screen or metaphor which both playwrights manipulated in order to discuss the anxieties endemic to their era.

Today, cases of syphilis are rare within most developed nations. Furthermore, if infection does occur, the stricken individual can be swiftly treated with a two week course of antibiotics, and within fourteen days, all vestiges of the infection, up to the tiniest remnant of a spirochete, are banished. Before the discovery of penicillin in 1937, however, an infection of syphilis resulted in a lifetime of illness. As the $16^{\text {th }}$ century came to a close, so widespread was syphilis that, according to London physician William Clowes, city hospitals were teeming with infected patients - indeed, their number was beyond count: "[I]n the Hospitall of Saint Barthelmew in London there hath bene cured of this disease by mee and three other with in flue yeares to the number of one thousande and more: I speake nothing of Saint Thomas hospital and other houses about the Citie wherein an infinite multitude are dayly in cure." We now know that syphilis is caused by the helically coiled, gram- negative spirochete Treponema pallidum; furthermore, we know that Clowes "cures" were, at their best, ineffective panaceae, and at the worst, treatments which could worsen a patient's symptoms, often hastening death. While there does not exist a conclusive theory regarding the origin of syphilis, we can be certain that populations were aware of its existence as soon as the late $15^{\text {th }}$ century. Perhaps it is for 
this reason that scientists have hypothesized that the disease originated in the West Indies, and was spread throughout Europe when explorers and sailors returned to the continent. The fact that indisputable reference to the affliction in European literature only occurred after the return of Columbus from the New World only adds fuel to that hypothesis. Like the new world itself, syphilis was foreign and entirely novel. While there are some historians who posit that syphilis had existed in Europe for centuries and was only mistaken for other afflictions, (Fabricius 5) it was not until the disease became particularly virulent following the frenetic movements of populations in the Age of Discovery, when populations which were wholly unprepared, both immunologically and curatively, that it is indisputably referred to in literature of the time. Once syphilis was given a name and a mythology, Treponema pallidum came to be used as ammunition by warring countries and factions: for example, "In England, syphilis was dubbed the Spanish sickness, the French pox, or the Neopolitan disease; on the Continent, therefore, the pox in all its nomenclatural guises were understood to originate elsewhere, to reside in and be transmitted by foreign bodies that had infiltrated bodies politic and natural" (Harris 44). Syphilis was not only an affliction grown and spread by the foreign and foreignness, it was also spread by what was unnatural, different, or novel.

It is conclusive that by the time that both Shakespeare and Beaumont were writing, the manifestations and appearance of syphilis were well known, a fact which is sufficiently reiterated by David Hoeniger in Medicine and Shakespeare: "By Shakespeare's time, the chief stages in the development of syphilis were widely familiar..." (220). In the absence of a reliable, effective treatment, syphilis was able to 
cause hysteria amongst populations, so great was the suffering provoked by it; of particular note is an outbreak which occurred in 1515 , brought back from soldiers returning from France (220). Syphilis, indeed all infectious diseases, held an inimical power over nations. It is easy to imagine how the constant threat of syphilis infection might affect the writing of poetry, fiction, and plays: if the threat was pervasive and ever - present, any writing, poetic or otherwise, could most certainly imbue the tone of literature with a certain spirit. Furthermore, it has been posited that Shakespeare, perhaps more than any other playwright and author, was interested in the workings of the body in general: "His plays and poems indicate how much he was interested in the body and mind in general, how they function when healthy, how they malfunction when disturbed or ill, and how body and mind interact" (11). What is perhaps more important is that Shakespeare's foremost concern (that is, in terms of disease) was venereal disease: "To no other kind of illness does Shakespeare allude as often as to venereal disease..." (219). Thus, we are aware that Shakespeare, like many of his contemporaries, was well - versed in the possible symptoms of many diseases, venereal or not. We also know that Shakespeare's awareness was heightened by a particular interest in disease. But what is perhaps the most important thing of all is that Shakespeare was also vested in the portrayal of syphilis in his works: "As critics have increasingly noted, images of syphilis cast a long shadow over Shakespeare's mature drama, particularly the so -called problem plays of the dark middle period" (Harris, 29).

In the following pages, I will discuss how both Shakespeare and Beaumont utilized syphilitic metaphors in order to indicate not only the overwhelming presence of 
syphilis within their society, but also in order to create alternate, heterotopic spaces wherein discussions regarding changing socio-economic and political realities could occur, and realizations regarding disruptive events could take place. Shakespeare used Hamlet to show social and political anxieties concerning the end of the Tudor line via the concept of the syphilitic body politic of King Hamlet, Prince Hamlet, and Claudius - a triad who, through lack of discretion and self-control, have infected all of Elsinore, and as a result, the whole of the nation. The ruling body politic, (ghost, prince, and usurping brother) grapples with its diseased body, thus its heightened awareness of the nearness of mortality, through entering and encountering a series of heterotopic spaces, wherein they are able to reach acceptance of a new state: death. I will show how the conclusion of the play urges community acceptance of death of another kind: the death of a long- standing political lineage, and its replacement by an alternative, and vital, line from the borderlands.

Beaumont, on the other hand, uses The Knight of the Burning Pestle to show social and community anxieties about changing economic systems and the engines that drive them. Here, though, the syphilitic body - The Knight of the Burning Pestle - is a figure or construct, symbolic and not real, yet able to contaminate all of Britain simply because, unlike the death of a single human body, his movements (and the energies and ideas which drive him) cannot be contained. Like the ruling tri-body politic in Hamlet, the singular knight formulates realizations about a changing society within the constructive space of the heterotopia. Unlike Hamlet, however, the Knight's journey of discovery cannot be contained. Astride his magnificent palfrey, he trots through, over, 
and atop each layer of the play, asserting his utter omnipresence. The Burning Pestle, like the economic changes occurring within England at this time, erupts everywhere. Instead of bringing death, however, this syphilitic body heralds, finally, community and laughter, and the piecing together of disparate societal fabrics, as opposed to the destruction of a royal court. In the pages which follow, I will first discuss the presence of syphilis within both plays, showing how the presence of that infection forces particular characters into reflective spaces of radical recognition. Of equal importance will be my portrayal of how these same spaces evince, first, the importance of spatial thinking to these Early Modern playwrights, and second, how they meant for these literary spaces to be used within their own communities to tackle the particular problems of disruptive regime change and radical economic shift. 


\section{CHAPTER I}

A Sore Distraction

Barnardo: Who's there?

Francisco: Nay, answer me. Stand and unfold yourself.

Barnardo: Long live the King!

The above dialogue comprises Hamlet's first words. Though brief, Barnardo and Francisco's exchange upon the ramparts of Elsinore can neither be dismissed as a mere introduction of minor characters, nor can the meaning of their words be mistaken for a simple utterance meant only to disclose the relieving sentinel's identity. These first three lines contain a most succinct diminution of, first, the palpable, crackling current of anxiety which so characterizes the play, and second, the overwhelming fear of things occulted, things dangerous. In the dark upon the castle walls, Barnardo inquires who he has met; he is countered by Francisco's interrogatory request that he "unfold" himself: he must reveal his identity, or more literally, open his cloak to show what hides beneath it. His response? "Long live the King!"

Within the play's first three lines, we view a compelling coupling of syphilitic metaphor and a marked anxiety regarding the "health" of the ruling body politic. In its primary and secondary stages, syphilis is an infection which hides itself uncommonly well. Sufferers are often asymptomatic for months, despite the appearance of the original infection-site chancre. The prevalence of asymptomatic carriers and a tendency to overlook or fail to realize the significance of the chancre often resulted in a sharing of microbes, both within marriages and illicit affairs alike. That is, the chancre went either 
unrecognized or misunderstood by many of the infected- or simply ignored. The chancre is more than a symptom- it is also a symbol. Because it initially appears only on the genitals- the "privates" of the infected- it in fact kept "private," or occulted. This very subject is discussed by Thomas More in Utopia: "Before marriage some responsible and honourable woman, either a virgin or a widow, presents the woman naked to her suitor and after that some upright man presents the suitor naked to the woman" (413). These actions were taken precisely to locate any unwanted marks symptomatic of venereal disease, so that the inclination to hide symptoms was avoided, and there would not be a need for hyper-vigilance within the marriage bed.

Another reason syphilis provoked such widespread hysteria was the prevalence of its transmission through non-venereal contact. When syphilis was still a "new" disease (and herd immunity had yet to be developed) "a syphilitic barber, an infected cup or towel, or a kiss from a diseased person were enough to pass on the disease" (Fabricius, 20). Facility of transmission resulted in an overly-vigilant, hysterical populace; their universal concerns manifested in the medical writing of the time: "It proceeds also by lying in vncleane lynnen, by wearing the garments of them which are infected, and by lying with such as haue any spyces of it...by sitting on the priuie after them, (the infected) and sometimes by treading bare-footed on the spettle of those which haue beene long corrupted" (Lowe B2r). So when Barnardo is asked by Francisco to "unfold," he is not only being asked to divulge his name and provide the correct password; rather, he is also being commanded to reveal himself as clean or unclean, syphilitic or as yet healthy. Barnardo's response, though seemingly counter-intuitive, is weighty indeed. In 
responding "Long live the King," he simultaneously ignores the state of his own body, and deflects anxieties towards the king's body: Is the king healthy? Will he, in fact, live long? The formulaic response seems to insist so; but the palpable anxiety of these opening words counters the legitimacy of this axiom. The truism becomes a shibboleth. What if the king ails - what would a state of "rottenness" portend? And if the king were sick, perhaps from syphilis, what would this entail for his heir, and for the entire state of Denmark?

Hamlet is a play of "unfolding." It is a journey into the nature of exposing the body, both physical and politic, for what it is: diseased, crumbling, and being towards death. Via the metaphor of the physical body, Shakespeare remarks upon Denmark's diseased body politic. But it is a play as much about "realizing" as it is a play about unfolding. As Barnardo reveals, self-realization, especially when one is faced with imminent death, can be nigh impossible. Within the play, three kings, representing Denmark's past, present, and future (old Hamlet, Claudius, and Prince Hamlet) are each forced to encounter and peer into their own health, and that of their kingdom; each must take his temperature, and the temperature of Denmark. In order to perform this act of self-diagnosis, all must enter spaces of heterotopia, only within and through which they are able to accept the failure of their bodies, and their state.

Prepared and poised for war, Denmark vigilantly awaits attack. What we must question -indeed, what has been questioned before - is from whence the true threat of war comes; is it internal, or external? Marcellus introduces the reader to this very same 
anxiety: why such levels of preparation for foreign war, when the real threat might be home-grown?

"Why this same strict and observant watch

So nightly toils the subject of the land,

And [why] such daily [cast] of brazen cannon,

And foreign mart for implements of war...

What might be toward, that this sweaty haste

Doth make the night joint-laborer with the day..." (71-78)

Horatio responds logically, stating that such preparations are being made in order to counter any possible attack made by young Fortinbras of Norway, seeking to avenge his late father's defeat to King Hamlet some years past. And, though Marcellus responds to this explanation by stating "I think it be no other," we must note that Horatio introduced his own explanation with the following caveat: "At least the whisper goes so" (80). Teetering on the brink of armed conflict, the Danes rely on hushed breath; they accept, at least at the play's outset, the most logical and visible explanation: that Denmark is now, as it has been for some time, locked in an interminable struggle with the Norwegians.

However, this logic is punctuated by the appearance of a purely illogical (and partially invisible) being: the spectral form of the deceased King Hamlet. Despite their insistence that the increased security measures within their state directly and absolutely correlate with a threat of an external martial attack, it is of note that the sentries link the appearance of the ghost (which, in Horatio's words, "bodes some strange eruption to our state") with the preparations for war. The fact that they recognize so easily this 
correlation speaks to the fact that the ghost is more than "a harbinger preceding still the fates/ and prologue of the omen coming on" (122). In my estimation, the ghost marks a distinct change in the way the Danes both perceive and feel about the health of their body politic. The first recorded encounter with King Hamlet's ghostly form creates a new type of felt space which the sentries reveal through questioning the reasons which might underpin his sudden appearance. The flood of questions provoked by the ghost's materialization expose the health of Denmark's body, and how her citizens feel the change within this metaphoric body.

While the sentries' inquires reveal the opening of this new felt space, it is the past actions of the former body politic (comprised of old Hamlet, Claudius, and Gertrude) which provide the conditions for its creation. As I will show, something is, quite literally, "rotten in the state of Denmark." A potential for a radically different form of lived and felt space, the heterotopia, was created in the moment that the spirochetae of syphilis wiggled through a breach in Denmark's protective layers, whether we conceive of them as Elsinore's sturdy ramparts, or the body of its rulers past, present, and passedover; however, that space is not entered until gestures toward acknowledging infection, be they figurative or literal, commence. That is, it is the actions which occurred prior to the wedge of time presented in the play which created the heterotopic space of syphilis; however, this space is uninhabitable- indeed, it is invisible and off- limits - until revealed by the sentries' opening dialogue, and the resulting rising action.

Any disease must have a reservoir from which to spring; that is, a host body (understood literally or metaphorically) which provides the conditions necessary for its 
incubation and growth. Within Hamlet, this reservoir is aptly characterized, physically and metaphorically, by the ruling dyad of Gertrude and Claudius, which because of its unclean nature, results in and furthers the behaviors which later cause the breakdown of the kingdom. Syphilis was "broadly considered to be a disease of sinful or excessive appetite;" (Harris 42) Gertrude and Claudius exemplify these two terms. It is intimated that before King Hamlet's death, Gertrude's lust for Claudius was so great, "as if increase of appetite had grown, by what it fed on" (I ii, 144-145). After his death, her race to Claudius's bed further marked her infidelity, which can be observed within the following lines:

"Within a month, Ere yet the salt of most unrighteous tears Had left flushed in galled eyes, She married- O most wicked speed: to post with such dexterity to incestuous sheets, It is not, nor cannot come to good" (1.2 154- 157) In saying "It is not, nor cannot come to good," Hamlet alerts the audience to the problematic origin of Gertrude and Claudius's union. Furthermore, he insinuates that there is something in their union which cannot be solved (or "healed") and which will cause grievous results. Gertrude, once desirous of her husband, behaved lasciviously with Claudius almost immediately following King Hamlet's death, thereby proving the quality of "luxury" inherent to both their characters. Theirs is not solely a bodily prostitution, either; consider for a moment 
the union of Gertrude and Claudius: do they not both benefit from the union? Consider Claudius' remarks upon his new wife:

"Therefore our sometime sister, now our queen, Th' imperial jointress to this warlike state, Have we, as 'twere with a defeated joy, With an auspicious, and a dropping eye, With mirth in funeral, and with dirge in marriage, In equal scale weighing delight and dole, Taken to wife... (I ii, 8-14)

Both Gertrude and Claudius's positions within the court have been made less tenuous; indeed, their statuses have been solidified by their hasty union, which is in turn solidified by their sexual contact. Claudius suggests that their marriage is shameful: that their relationship is one of prostitution in that the item bought is a continuance of power, and the currency is sex.

Furthermore, the nocturnal activities popular within Elsinore further manifest the type of amoral, excessive court kept by Gertrude and Claudius, this same reservoir of infection:

"The King doth wake tonight and take his rouse, Keeps wassail, and the swaggering up-spring reels, And as he drains his draughts of Rhenish down, The kettle-drum and trumpet thus bray out The triumph of his pledge" $(1.4,8-13)$. 
Prince Hamlet's observation regarding the court's carousing provides yet another clue concerning the lapsed and depraved nature of the Danish court. A particular, privileged group found itself at elevated risk for infection: the nobility. "A risk group of particularly interest to historians and one which appears frequently in the sources is the nobility, particularly its members at court. The term "court disease" was coined...towards the end of the $15^{\text {th }}$ century, as one of the numerous names for the new disease, syphilis... the disease was known as 'morbus curialis' because it was always to be found in the vicinity of a court" (Fabricius, 154). It is not difficult to see the connection between the excessive taste for drink and an eventual infection with treponamatosis; indeed, within the court, such debauchery was called "luxury," and the eventual pollution of the body with syphilis was considered, for lack of a better term, somewhat "normal" (163-164).

As the Danish court was led by such a licentious union, the remainder of the court had no hope of avoiding the stealthy germ of syphilis, nor could they avoid transmitting it to the Danish people. Syphilis infection can be understood as a "revenging copulation;" that is, the conditions of possibility for infection can be, and must be blamed upon the careless nature of Gertrude and Claudius's sexual relationship and those courtiers similarly "active" within Elsinore. Their ill behavior modeled the same behavior for others, thereby increasing the spread of disease. As the ruling couple would have set the precedent and style at court, it is natural that their subjects would follow their lead. And so, the result of the King and Queen's relationship is the creation of a channel - or doorway - through which 
the deadly disease (be it figurative or metaphorical) can pass; the prevalence of luxury causes the national immune system to weaken. Ultimately, this vulnerability will open the gates of Elsinore and allow for the entrance of the "enemy."

A perfect example of this precedence setting contamination can be observed in the relationship between Prince Hamlet and Ophelia. Here, we can observe a more metaphorical reservoir of infection, for though they do not partake in as much amoral revelry as the king and queen, all those about them are concerned with infection. The language that is used by and regarding these two characters (at least related to prostitution and/ or unchecked sexual appetites) is most likely more symbolic than factual. I find the following paternal advice to be of particular importance:

"And keep you in the rear of your affection, Out of the shot and danger of desire. The chariest maid is prodigal enough If she unmask her beauty to the moon. Virtue itself escapes not calumnious strokes. The canker galls the infants of the spring Too oft before their buttons be disclos'd, And in the morn and liquid dew of youth Contagious blastments are most imminent" $(1.3 ; 34-42)$

While the voice of Polonius is one often marked by a palpable, supercilious pedantry, these lines contain a kernel of undeniable truth: no matter the extent of your virtue, you too could fall victim to an oppressive sexual appetite, whether it 
be your own or someone else's. Furthermore, we must note the terms which Polonius utilizes to describe the effects of failing to curb one's natural appetites; hidden smack in the middle of the line is a term which cannot be ignored: canker. Though the specific manifestations and symptoms of syphilis infection will be discussed at greater length shortly, the word demands comment. "Canker" is merely an Anglicized form of "chancre;" this is of undeniable importance, for the "chancre" of which I am speaking is the term for the first round nodule or sore signifying infection with syphilis. The origin of the term "chancre" can be traced to "cancer," which, at this time in medical history, was used to "describe venereal lesions in the secret parts" (186). In effect, Polonius is warning his daughter to beware her passions, lest this "canker" infect and ruin her youth. We see that the physical bodies of both Claudius and Prince Hamlet - two parts of the triple body politic- create reservoirs of infection: either their behavior or the language employed about them makes these characters appear susceptible to disease.

The source of infection is also the reason it so persists and grows. After a single reading of Hamlet the reader is well acquainted with the sexual appetites of the body politic, and after a number of readings, King Hamlet, Claudius, and Prince Hamlet seem abjectly lecherous. Claudius and Gertrude (via Claudius) are the source of the disease. They infected and killed King Hamlet, and the lax morals they espouse are contributing to the infection of their entire court. The royal house of Denmark creates this "reservoir of infection" through their sexual 
depravity; syphilis was, after all, "broadly considered to be a disease of sinful or excessive appetite" (Harris, 42).

Once the proper conditions for the spread of disease are in order, the infecting organism begins to do his work; the organism being, of course, syphilis. It is clear from numerous allusions that, while Shakespeare may not have made it his priority to blatantly state that Denmark (through the adulterous relation of Claudius and Gertrude) had become a nation wholly diseased by the dreaded "foule sickenesse," the clues, which would have been more than subliminal to original spectators of the play, are glaring. These clues are particularly clear in the case of King Hamlet, the first "victim" of the spreading illness. As the ghost, his revelations to his son Prince Hamlet clearly indicate that his "murder" began with his infection. Of course, he does not stake this claim of infection outright; instead, his charges appear occulted in three different metaphorical disguises: that of the serpent, and that of the twin poisons hebona and mercury.

In Shakespeare's day, the difference between herpes, leprosy, and syphilis was relatively unknown. Thus, a look into the etymologies of both the terms "herpes" and "leprosy" might help us to understand how Elizabethans understood syphilis, as the terms were relatively interchangeable (Fabricius 3). Coincidentally, both terms possess strikingly similar roots. "Leprosy" is derived from the Greek "lepra," which is the feminine form of "lepro," meaning "scaly." "Herpes" is derived from the Greek term "herpeton," which means "a creeping thing." If these two etymologies are put together, they form a "scaly, creeping thing;" perfectly describes a serpent, which was, and still is a figure of extreme importance in syphilology (Fabricius 7). 
Not coincidentally, the imagery of the serpent arises in Hamlet, at the heart of the scene where the ghost of Prince Hamlet's father describes his "murther most foul." When recounting his killing, he states,

“'Tis given out that, sleeping in my orchard A serpent stung me, so the whole ear of Denmark Is by a forged process of my death Rankly abus'd; but know, thou noble youth, The serpent that did sting thy father's life Now wears his crown" (I.iv; 36 -39)

The allusion is clear. The bacteria of Treponema Pallidum resembles a snake. Helically coiled, once it has found passage within the body, it adopts a wriggling and creeping movement; "the spirals... are wider, flatter, more sinuous in character and irregular; the organism is more refractile and its movement is snakelike... (Kingsbury, 282). The serpent perpetrator here can be identified in one of two ways: either King Hamlet was killed by the serpent of syphilis proper, or, although he was killed by Claudius, this murderous brother represents and carries the disease, for "the serpent that did sting thy father's life/ Now wears his crown" (I v 38-39) The relationship shared by Claudius and Gertrude is both diseased and disease itself.

When considering this passage, we must also examine the ghost's assertion that he was murdered while sleeping. The disease itself would have been passed from host the infected Gertrude- to King Hamlet's new, susceptible body through another act of sleeping. The ghost, aware of the consequences of Gertrude and Claudius's adultery, 
expresses not only that he has been stung by the serpent, but "so too is all Denmark abus'd;" that is, infected. Both the contamination of his body and the means by which Claudius has wrested the crown are "forged;" these are false or fake processes borne out of the infidelities of adultery.

Another suggestion that syphilis was the agent of infection and death is indicated by Shakespeare's insistent identification of hebona as the killing poison:

"Upon my secure hour thy uncle stole With juice of cursed hebona in a vial, And in the porches of my ears did pour The leprous distilment, whose effect Hold such an enmity with blood of man That swift as quicksilver it courses through The natural gates and alleys of the body" (I.iv. 60-66)

As a choice of poison, hebona is of extreme importance, for it was used as a cure for syphilis in the $16^{\text {th }}$ century. Though this fact may seem to counter my theory, I assure you that quite the opposite holds. Hebona was derived from the gum of the guaiacum tree, which was boiled and reduced until it created a fine paste; at this point, the patient was made to sit in a sealed room and the concoction was added to water and placed over a flame. The ill were to sit within this room and sweat until they were "pure," and the syphilis had left their body (Fabricius 48). I include hebona as one of the signifiers of syphilis within the text for a number of reasons. First, in referring to this particular wood instead of any other, we see that Shakespeare knew of hebona's supposed curative 
properties. Secondly, and perhaps more important, is the fact that hebona very rarely cured anybody. Hebona's poor reputation was widely known (Quetel, 60). While it may have helped management of symptoms in the short- term, hebona more often than not poisoned those who employed it: "guaiac was anti-lueticum...it acts as a poison producing the same symptoms as the disease for which it was supposed to be a cure... Shakespeare's contemporaries regarded guaiac as poisonous and just as dangerous as quicksilver..."(Fabricius 47). The supposed cure in fact only exacerbated the symptoms of syphilis and brought death upon sufferers more quickly. It was "cursed" because it accentuated the disease, rather than diminishing it. Once syphilitics had taken the hebona cure, their symptoms worsened and quickened. They felt more pain, and were easier to identify. Far from being a potion, hebona was in fact a poison - a poison used to identify and further inflict the bodies of the sick and infirm. In a similar manner, the quicksilver mentioned in line 65 was, and still is, often understood to be synonymous with mercury; it, too, was used as a treatment for syphilis, often with disastrous results: excessive use of mercury, as either an ointment or a friction, resulted in "shaking and paralysis, the loosening and loss of teeth, etc" (Quetel 31). Like hebona, quicksilver too exacerbated rather than excised the disease.

As I stated previously, Claudius and Gertrude must be seen as both the agent/origin and the metaphoric embodiment of syphilis, as they are the "serpent" who "now wears his [King Hamlet's] crown." While Claudius is "the germ," he is also the first host of the disease. His treachery transmitted the disease to King Hamlet, but only through the intermediary of Gertrude, who he first infected. The transmission of syphilis 
from Claudius to Gertrude certainly would have been sexual. She would have then transmitted the infection to her lawful husband, King Hamlet. Of his former wife, the ghost of King Hamlet says: "Leave her to heaven, And to those thorns that in her bosom lodge/ To prick and sting her" $(1.4,8688)$. Though these lines refer to Gertrude's conscience and her necessary guilt for her incest, I believe that they also mean that each time she is intimate with Claudius, she is "pricked" and "stung" not only by the lecherous snake, (e.g., Claudius' penis) but also by the germ of syphilis that his genitalia carry and convey to her. In continuing her liaison with the usurper Claudius, she is further corrupting the nation, or "Let[ting] the royal bed of Denmark be/ A couch for luxury and damned incest" (4.1 82-83). Luxury, of course, was a term synonymous with venereal disease.

Further evidence of Gertrude's contamination, and her son's awareness of this impurity in their midst, comes during the closet scene in which Prince Hamlet berates his mother for her relationship with his uncle, when he states the following:

Lay not that flattering unction to your soul, That not your trespass but my madness speaks, It will but skin and film the ulcerous place, Whiles rank corruption, mining all within, Infects unseen. Confess yourself to heaven, Repent what's past, avoid what is to come, And do not spread the compost on the weeds To make them ranker" (1.4 144-152) 
"Rank corruption" could very easily refer to the disease itself, and "that ulcerous place" would refer to either the chancre, or to the skin lesions so common to syphilis. Claudius's "flattering unction" acts as a metaphorical hebona or quicksilver meant to cure, but fails to do so. "Trespass" refers, once again, to the source of the infection - adultery. Gertrude has "trespassed" the boundaries of an appropriate relationship with her former husband's brother. "Infects unseen" returns, of course, to the problem of the hidden nature of syphilis. In telling Gertrude to "avoid what is to come," Hamlet is cautioning his mother to remove herself from Claudius and his infecting "agent;" likewise, when he urges Gertrude to cease "spread[ing]" the compost, he is explaining that if she allows her sexual relationship with Claudius to continue, the disease will spread to all Danish "weeds," infecting them as well.

Also of note is the appearance of King Hamlet's ghost within the closet. He is clad in his night-gown, suggesting that his murder, literal or metaphorical, was committed while he wore this garment. We must assume that Gertude's adultery with Claudius began before King Hamlet's death - as I have explained, it was through their adulterous relations that King Hamlet was murdered. Gertrude continued assertion of "Alas, he's mad!" signifies that she is unable to come to terms with her condition; thus, the "flattering unction" can be seen either as an unguent to soothe the papules and nodules which commonly appeared in the secondary stage of syphilis, or in a metaphoric sense, to clear her conscience of the knowledge that she, through her actions, has become diseased, "killed" her husband, and has put the nation at risk. 
Claudius reasserts the above notion when he expresses the following:

“...So much was our love,

We would not understand what was most fit,

But like the owner of a foul disease,

To keep it from divulging, let it feed

Even on the pith of life" (IV, ii 19-24)

Here, Claudius not only uses the language of disease to express his guilt, but it can be argued that he also is the owner of a "foul disease," and because of his shame regarding it, has "let it feed" on all he comes into contact with. While the physical germ may have infected the nation with syphilitic poison, it is Claudius' need to preserve the private nature of the disease which allows it to so corrupt the state. He cannot "divulge," or confess his transgressions. Like a foul disease, these transgressions grow in virulence the longer they remain covert. Left inside the body without the curative release of confession, they increase in septicity, and feed on the very marrow of his life: his position as ruler of Denmark.

There are numerous other characters that may be infected with syphilis. Certainly, the stakes are greatest with Hamlet and Ophelia. As for his sister, Laertes' words to Hamlet in the graveyard scene seem to reflect a belief that Ophelia, as foreshadowed by Polonius, has "been galled by canker:" “O, treble woe/ Fall ten times [treble] on that cursed head/ Whose wicked deed thy most ingenious sense/ Depriv'd thee of..." (IV.I 23- 236) Perhaps Laertes refers to the "cursed head" of Prince Hamlet, whose "wicked deed" was sexual intercourse with Ophelia, which resulted in her 
infection with syphilis and the loss of her cognitive powers. After all, we are unaware how much time passes during Act V; certainly, enough time could have passed for the disease to so riddle her brain as to cause a loss of her "most ingenious sense." A frightening effect of tertiary syphilis is dementia paralytica, or insanity (Fabricius 65). Ophelia's failing mental health could, then, be viably explained by the ravages of syphilis. Prince Hamlet's belligerent split with Ophelia had purpose then: he feared infecting her with the "kissing carrion" of syphilis. He says: "Get thee to a nunn'ry, why wouldst thou be a breeder of sinners? I am myself indifferent honest, but yet... I am very proud, vengeful, ambitious, with more offenses at my beck than I have thoughts to put them in...We are arrant knaves, believe none of us. Go thy ways to a nunn'ry...” (III, i 120-128). Though Hamlet's words are often perceived as angry, or as proof of his failing mind, (as Ophelia herself believes) what if he is actually cautioning her? Hamlet professes that he is many things, but not a breeder of sinners; that is, he will not allow for his contagion (sin) to spread via Ophelia and any children that their union might produce. "No more marriages" is the only way Hamlet can think of for Ophelia to avoid further ravages of the disease, though it may already be too late. Thus, we can see her insanity as the result of either infection during her brief liaison with Hamlet, or his abandonment of her (as a result of his desire to keep her free from his disease). In this light, Hamlet's comment to Laertes at Ophelia's burial is given new meaning: "I lov'd Ophelia... What wilt thou do for her?" (V, i 255-57).

And so we must turn to Hamlet himself, and the question of his own "purchase" of the disease. Certainly, it is interesting to posit that Hamlet has also been infected. In 
Act V Scene ii, he admits to having a "sore distraction" (212). Although readers and critics alike have typically seen this as a reference to his mental state, could it not also be an apt descriptor of his physical deterioration? Both of these terms can be seen as hinting toward syphilis infection. "Sore" could be referring to the sores so common to the disease, and "distraction" could refer to compromised mental faculties. Of the transmission to Hamlet, however, one cannot be sure. There is the slight chance that, provided Gertrude had been sleeping with Claudius before Hamlet's birth, he could have congenital syphilis, which can manifest in many of the same modes as acquired syphilis. But, I believe that this infection is more metaphoric than it is literal - that we must see the corruptive influences of this adulterous court, and see how a lack of discipline and restraint in governing bodies results in the sickening, corruption, and downfall of a body politic.

I have established both the possibilities for literal and metaphorical presence of syphilis and the "infection" of several characters within the state of Denmark. More important than symptom, however, are the effects of syphilitic infection. Nothing more than physical suffering forces the subject to focus on the body; that is, disease, whether metaphorically or literally rendered, requires that subjective attention be paid to its mere existence. The body can no longer ignore that it $i s$, and that it is fallible. I posit that in Hamlet, we observe that syphilitic infection creates a space like no other - one that ushers the diseased into an uncomfortable, yet privileged reflective space which I will henceforth refer to as heterotopia. It is not the simple presence of syphilis within the state that creates the heterotopia; rather, it is awareness of its presence within the human 
body: “...heterotopias always presuppose a system of opening and closing that both isolates them and makes them penetrable. In general, the heterotopic site is not freely accessible like a public place...To get in one must have a certain permission and make certain gestures" (Foucault 3). The heterotopic spaces within Hamlet, then, are opened following recognition of the germ the body carries within itself, and is able to transmit to others. These same spaces are only closed when reparations for the spread of the disease have been executed. Following Foucault's definition, the heterotopias within Hamlet are not public places - while they may occur within a public sphere, they are only visible and experienced by a member of the body politic who is experiencing the bodily crisis caused by syphilis infection. By privileged, Foucault means that any heterotopia is tailored to fit a permutation of the actor's conscience and body - that is, these spaces are bespoke, in a way - to individual physiognomy and guilt. The human body itself is a heterotopia; it is the most private, privileged space of all - but in order to realize the ultimate realness (thus the coming definite end) of this private space, the human bodies of the body politic must enter other spaces marked by their heterotopologic features. These separate (yet still privileged) spaces provoke intense reflection: that is, seeing the body where it is not, and observing the body for what it is.

Though the members of Denmark's body politic were previously infected by syphilis, the appearance of King Hamlet's ghost is the first instance wherein heterotopological space materializes, and is felt by the characters within the play, the audience, and the reader. The ghost, neither living nor dead, spectrally embodies the mirror-like space of heterotopia. As a "spirit, doomed for a certain term to walk the 
night," the ghost is in a "placeless place;" (Foucault 1) it inhabits an immaterial body which is "like" him, but is not his flesh and bone form. Foucault describes the space of heterotopia as both an impossible place, and a real space, for within the heterotopic space, "[you] see [your]self where [you] are not, in an unreal, virtual space that opens up behind the surface, [you] are over there, where [you] are not... a sort of shadow that gives [your] own visibility to [your]self, that enables [you] to see where [you] are absent" (3). The ghost moves upon the ramparts, moves its mouth to speak, utters words and demands avowals, yet quite simply, is not. Its "questionable shape" is simultaneously of the real, yet inhabits a realm of the unreal; it straddles two separate planes of being, and, in its movement to rationalize the fact of both, forces them to collide. In actualizing the idea of Derridean singularity, the creation of heterotopia results in an interruption of natural spatial orders. Until the mechanism of disease is removed from the kingdom of both the singular body and of the body politic, these planes will continue to collide. The heterotopic spaces found within the human body and the body politic must be banished, in order to restore stability to Denmark. Of the ghost, Hamlet inquires "Say why is this? Wherefore? What should we do?" The ghost's answer, and resulting plan, is revenge. It is only through "reveng[ing] his foul and most unnatural murder" that order can be restored to the kingdom - both of the singular body, and the state. The ghost, it would seem, is "doomed for a certain term to walk the night;" deliverance will not come until his infection has been avenged.

The prince, now aware of the presence of rank poison within his demesne, enters that reflective, melancholic space for which he is so well-known. The ghost of his father 
acts as his first heterotopic "mirror space." In the likeness of his father, Prince Hamlet discovers his absence from "place where he is;" that is, he recognizes in his body the poison (or at least the strong possibility of being poisoned) which killed his father, and his father's death in himself. Foucault says of the heterotopia, “...this gaze...[is] directed toward me, from the ground of this virtual space that is on the other side of the glass, [and] I come back toward myself; I begin again to direct my eyes toward myself and to reconstitute myself there where I am." In his father's likeness Hamlet sees himself, and has to "reconstitute" his conception of his reality, given this new knowledge regarding the state of his body. Both his physical body and the state body are now spaces which must be viewed differently, exposed as they are to vile infection. They are now mere ephemera, and the fact of their evanescence forces Hamlet, at first, to enter the selfmaking space of the heterotopia- that very real space in which he must countenance the fact of his crisis, and his mortality. This unnerving reminder, now "hic et ubique," (so ubiquitous that when Hamlet "shifts his ground," the voice of the ghost calls up to him again) cannot be avoided, yet cannot be suffered to exist. It is left to Hamlet to realign these spatial inconsistencies and set Denmark to rights, both facts of which he is well aware: "The time is out of joint - O cursed spite/ That ever I was born to set it right!"

Hamlet first shows heightened awareness of his diseased body and his heterotopological surroundings through his conversations with Ophelia. Consider for a moment that he is now aware of the poison they both contain within their bodies (members as they are of this luxurious state). He warns Polonius to keep Ophelia from him: "For if the sun breed maggots in a dead dog, being a good kissing carrion - have 
you a daughter...Let her not walk I' the' sun. Conception is a blessing, but as your daughter may conceive, friend, look to't." "Sun" could also refer to "son," and the breeding of maggots entails passing the disease onto his offspring, via the "dead dog." Although she yet lives, Ophelia will be doomed by the spirochetae already concealed within her body, or shortly to be placed there by a continued proximity to, or contact with, Hamlet. These are not wild and whirling words - indeed, they are meant to warn Polonius to keep her far from him. Of course, this might be understood less specifically. Hamlet, now aware of the diseased state (metaphoric or literal) both of the human and state body, is simply disgusted by thoughts of further relation with members of the opposite sex. His musings on the body continue: “... the satirical rogue says here that old men have grey beards, that their faces are wrinkled, their eyes purging thick amber and plum - tree gum, and that they have a plentiful lack of wit, together with most weak hams..." The prince describes himself as a man old before his time, displaying some of the most disturbing physical and psychological symptoms of syphilis. He returns to cautioning Polonius about his daughter's physical health. Hamlet once more displays his entrance into the reflective, heterotopological space in his conversation with Rosencrantz and Guildenstern, in which he refers to himself as "the very quintessence of dust." A reference to his still - living body as mere dust evinces a protracted cognizance of a mortality surely imminent.

Foucault characterizes the heterotopia by saying it is where we are, yet simultaneously, where we are not. The three figures of Denmark's body politic all embody and inhabit heterotopic space: that is, they are this space, but in order to 
recognize the changed state of their human bodies, I posit that both Claudius and Hamlet must enter other heterotopic spaces in order to encounter their approaching deaths, and the death of their political line.

Aware of the strange eruption the ghost signals, Horatio warns Prince Hamlet not to follow the specter when it summons him. Prince Hamlet disregards his cautions and follows the ghost, who tells him the "tale to harrow his soul." The ghost is not only telling his son of his murder by his own brother, he is also imparting to Hamlet the knowledge that Claudius, and he himself, have been infected by the "sore affliction," both figuratively and concretely speaking. Prince Hamlet is all at once ushered into a new space of knowledge - one in which he must recognize, first, that his life will soon end, and second, that in absence of an heir, the Danish line will end. The revenant's plea that his murder be avenged is not only to release his soul from purgatory, but to release the state from its poisonous, diseased rule. Denmark is now in the thrall of "luxury and damned incest," and the only way to remove the threats posed to the nation via "luxury" is to remove its prime agent and vehicle.

Hamlet must race to set things right before infection can further spread. In order to secure Claudius' confession, he prepares to construct a space expressly tailored to his uncle's guilt, believing that Claudius will view the action of the play, and confess his brother's murder:

"I have heard

That guilty creatures sitting at a play

Have by the very cunning of the scene 
Been strook so to the soul, that presently

They have proclaime'd their malefactions:

For murther, though it have no tongue, will speak

With most miraculous organ."

The play, which Prince Hamlet calls "The Mousetrap," is "the image of a murder done in Vienna;" obviously, Hamlet has chosen this particular piece so that he might, as he himself has admitted "catch the conscience of a King." Furthermore, the far-off location of the play metaphorically removes syphilitic infection from Denmark, instead projecting its ravages into a foreign, possibly hostile zone. In order for Claudius to implicate himself in his brother's murder, it is important that he view his crime not only acted by another individual, but in a another (albeit mental) geographical space. Indeed, Lucianus's actions and speech could have been the same as Claudius' himself before he murdered his brother, so similar are they:

"Thoughts black, hands apt, drugs fit, and time agreeing,

Confederate season, else no creature seeing,

Thou mixture rank, o midnight weeds collected,

With Hecat's ban thrice blasted, thrice infected,

They natural magic and dire property

On wholesome life usurps immediately" (94).

The actions depicted in "The Murder of Gonzago" force Claudius into a reflective space, wherein he countenances his guilt and his body. Immediately after viewing Lucianus's actions, so similar to his own, he rises and hurries to exit the scene. When the audience again sees him alone, he confesses his guilt, saying: “ $\mathrm{O}$, my offense is rank, it smells to heaven, /It hath the primal eldest curse upon't, /A brother's murder." 
The fictional Gonzago's murder thrusts Claudius into a privileged, private space wherein he is taunted by guilt caused by the murder he committed. As he sees his double perform upon the stage the very same action which he himself committed only two months prior, he enters the no-space created by the imbrication of space and time. His transgressions encounter him in his present time, upon the stage which is in his view. This collision of two separate times results in the creation of a space which is hyper - real and as such, hyper reflective. Claudius also seems to realize the effect his actions have had on the state, calling it, "wretched state," with a "bosom black as death." He sees that Denmark under his rule - at least one with Prince Hamlet in it - is doomed to fail. He, like Hamlet, is driven to dispel the heterotopia via revenge, which in his case, is constituted by Hamlet's banishment to England.

However, it is Hamlet's banishment to England which indirectly causes Denmark's demise. Before the prince is forced to board the ship, we see another marked change in the character and resolve of Prince Hamlet. It is the sight of Fortinbras' army marching for Poland which galvanizes his actions. He says,

"Witness this army of such mass and charge,

Led by a delicate and tender prince,

Whose spirit with divine ambition puff'd

Makes mouths at the invisible event...

How stand I then,

That have a father kill'd, a mother stain'd...

And let all sleep, while to my shame I see

The imminent death of twenty thousand men, 
That for a fantasy and a trick of fame

Go to their graves like beds, fight for a plot

Whereon the numbers cannot try the cause.

Which is not tomb enough and continent

To hide the slain? O, from this time forth,

My thoughts be bloody, or nothing worth! (47 - 65)

The observation of Fortinbras and his army from afar creates another heterotopic space within which Hamlet can reflect upon the fortunes and future of both himself and his erstwhile nation. Like Hamlet, Fortinbras is the child of a father murdered. Also like Hamlet, he seeks revenge for his father's unwarranted demise. In the view of Fortinbras at the head of an army, commanding troops with revenge as his purpose, however, Hamlet sees an uneven reflection, where the similarities should stand out more than the differences. That is, he sees how he ought to be, contrasted with how he truly is. The potentiality for being causes Hamlet to act.

When Hamlet is next mentioned, it is peripherally. We, the audience, are only permitted to hear about what transpired aboard the ship bound for England, making the ship the most privileged, private space of all. It is my claim that the ship became Prince Hamlet's heterotopia of crisis; that is, a space "reserved for individuals who are, in relation to society and to the human environment in which they live, in a state of crisis... a heterotopia without geographical markers" (Foucault 2). When he at last arrives back at court, Hamlet tells Horatio that aboard the vessel, he "infinite withdrew/ to mine own room again," realizing while alone the plot at work against his life - that his "head should 
be strook off" (141). It is only when Hamlet is "benetted round with villanies" that he is able to act, forging an "earnest conjuration from the King," (142) and sending Rosencrantz and Guildenstern to their deaths. Truly, a "sea-change:" upon the boat, within his chamber, Prince Hamlet has been forced to observe himself and the oath he made to the ghost of his father. He has been tasked with avenging his father's murder, thus with ridding Denmark of the poison created by the presence of disease. Within the heterotopia created by the floating space of the boat, he realizes his plan and what he must do in order to carry out his father's wishes. Hamlet validates his actions towards Rosenencrantz and Guildenstern, saying to Horatio,

"Does it not, think thee, stand me now upon -

He that hath kill'd my king and whor'd my mother, Popp'd in between th' election and my hopes, Thrown out his angle for my proper life, And with such coz'nage - is't not perfect conscience To quit him with this arm? And is't not to be damn'd, To let this canker of our nature come In further evil?

Prince Hamlet so much as confesses to Horatio that with this new resolve, he is full ready to murder his uncle, for if he does not, the "canker" created by Claudius' mere rule will only flourish and continue infecting the innocent, as it has his father, Gertrude and himself. This resolve is reached within the confines of the ship, its very structure and separation from Denmark conducive to radical self-discovery. Of the boat in particular, Foucault states, "it is a floating piece of space, a place without a place, that exists by itself, that is closed in on itself and at the same time is given over to the infinity of the sea 
and that, from port to port, from tack to tack... it goes ..far ...in search of the most precious treasures... The ship is the heterotopia par excellence.” (4).

A graveyard, like a ship, is a unique, unparalleled space wherein one is forced to view the juncture of space and time. Says Foucault, “...the cemetery is indeed a highly heterotopic place since, for the individual, the cemetery begins with this strange heterochrony, the loss of life, and with this quasi-eternity in which her permanent lot is dissolution and disappearance" (4). However, while within a graveyard, we are present in the space it provides, but do not occupy it fully: that is, we are not dead and buried within its confines. Like the ship, it is a place where we may remain only temporarily. Also like the ship, the temporary nature of the graveyard enforces upon visitors a different place of being. Within the graveyard, Hamlet confers with death and reaches conclusions regarding the coming reality of his own. It is a collision of a particular space, and the time he has remaining, which further influences Hamlet to act. Within the graveyard, he is yet he is simultaneously not. The reality he occupies is radically different than that of the reality of the occupants of the cemetery, and he is briefly thrust into the space they occupy.

Once within the graveyard, he observes the clowns burying bodies and remarks upon the lives those same skulls, bedecked in flesh of course, may have once lived. When he asks who will occupy the grave being dug, the clown responds, "One that was a woman, sir, but rest her soul, she's dead" (135). Prince Hamlet sees that in death, he will become what he is not, or he will not be what, and who, he is presently. I posit it is for that same reason that so soon after his visit to the graveyard, he makes his final actions: 
he will only be Prince Hamlet for a short time now, and must complete the task meted out to him by the "likeness" of his father.

The state of heterotopia into which Denmark has been thrust vanishes upon the deaths of the infected, and the reentry of Fortinbras. It is he who will cure the nation, and is given Prince Hamlet's blessing: "But I do prophesy th' election lights/ On Fortinbras, he has my dying voice (337-8). The "carnal, bloody, and unnatural acts/ ...accidental judgments, casual slaughters/... deaths put on by cunning and forc'd cause (363-65) are remedied by the Norse prince, who, "[has] some rights, of memory in this kingdom/ which now to claim [his vantage] doth invite [him] (371-2). The diseased body politic of King Hamlet, Claudius, and Prince Hamlet is, through death, utterly banished from the nation. The disease of their rule follows them in death, and Denmark is once again ruled by a healthy body. The illusory space of the heterotopia is punctured with the arrival of a new ruler, who will lead the nation back into unified, shared space, as opposed to privileged, reflective, and diseased, space.

Thus, the presence of syphilis within Denmark creates the conditions of possibility necessary for the heterotopic state to form. The heterotopia, in turn, creates the characters' ability to reflect upon their previous actions, their own diseased bodies, and what must be done in order to "cure" the nation of its most grievous bodily ailment. That cure is death, and rule by a new line.

Hamlet was, of course, performed in the theater, yet another heterotopic space. The theater "brings onto the rectangle of the stage, one after the other, a whole series of places that are foreign to one another" (Foucault, 2). The theater also brings to the 
audience a series of places that are, simply, foreign. Natural to spectatorship is a sort of plunging into a new space, one which is played upon the stage for all present, but which is also the viewer's alone. The stage is peculiar in that it is a shared space, but a site made available for one's individual understanding and the formation of individual conclusions. Denmark was foreign to spectators of Hamlet, but parts of the drama were all too familiar.

The introduction of syphilis to Europe at the beginning of the $16^{\text {th }}$ Century provoked a chaotic reign of terror which persisted roughly until the 1550's. At that time, some herd immunity was developed, and the progression of the disease seemed to slow; of this phenomenon, physician Ambroise Pare wrote, "the pox as it is at present is much less cruel and much easier to cure than at the time it first appeared; it is clearly becoming milder with every passing day..." (Quetel 51) Syphilis did not, however, disappear - it merely “....kept to a 'cruising speed,' foreshadowing the insidious and discreet character it was subsequently to adopt." By the time Hamlet was played in 1601, syphilis was an accepted, yet feared part of the social fabric; furthermore, "sixteenth-century literature was quick to seize on such a rich theme, with the opportunities it offered to those with a bent for moralizing or social satire..." (67). Shakespeare's London was a promiscuous city, of which "increased vagrancy, prostitution, and moral laxity all contributed to a dramatic awareness of venereal disease such as syphilis" (Fabricius 103). Shakespeare's writing would have been affected by his daily observations; he was witness to the social breakdown of the city, especially working within the sector of the theater, which "promiscuity and prostitution were salient features... which to an extent reflected the 
conditions of society in general." The great poxy disintegration of London was reflected through the theater, which "depict[ed] this situation with its numerous references to brothels, pox, barber surgeons, and medical treatments for venereal disease" (174). As I have shown, syphilis is one of Hamlet's "undersongs," and the images provided by this undersong - corruption, decay, and degeneration - all lend unity to the play's dramatic structure.

But the heterotopia created by the stage does more than reveal the prevalent social condition of disease; more importantly, within the degeneration of Denmark's body politic, a metaphor for Britain's decaying rule is created. Hamlet reveals a crisis of succession; so does the stage upon it was played. The stage, then, becomes a privileged, personal space whereupon spectators are able to countenance the political crisis in their own midst.

It has been suggested that the "cult of Gloriana" is more fiction than fact; that is, that during Elizabeth I's rule, the English were in a constant state of anxiety: “.... fair number of her loyal subjects seem to have been more of less constantly afraid and insecure. They constantly reiterated their fears of disorder, and their conviction that the realm was secure against neither internal divisions nor external enemies" (Sharpe 12). This tension only mounted when Elizabeth began to age, yet refused to name a successor: “...there was a continual juggling for position among courtiers and politicians, a natural consequence of the awareness that the Queen was old and her death could not be postponed indefinitely" (14). We can view the tensions between the Cecil faction and Robert Devereux, Earl of Essex, which bred and eventually resulted in Essex's rebellion 
in 1601 , as the most dramatic indicator of this increasing instability and societal anxiety (although, coincidentally, Essex biographer Robert Lacey chalks Essex's "erratic behavior and irrational outbursts of emotion" up to late syphilis of the central nervous system [201-02]). Devereux, previously one of the Queen's favorites, was “angry to hear of plans afoot to place the Spanish Infanta on the throne instead of James after Elizabeth's death,” (Kinney 319) although there was no proof to suggest that this was a viable option (Elizabeth herself was not amenable to this selection, in fact). Using little more than a rumor as credibility, Devereux managed to drum up supporters comprised of Puritans, Catholics, adventurers, men he had knighted, wanderers, and the poor. Terrified of a possible foreign successor to Elizabeth, the anxiety of Devereux and his supporters boiled over into full-scale rebellion. Though this rebellion was unsuccessful, it evinces the extent to which the English felt threatened by the imminent death of their ruler, and the type of chaos the end of her rule might provoke. The sentries' anxious whispers at the play's opening would have struck a chord with the audience: what if our Queen is not well? What if she does not live long? Hamlet's audience would have felt the anxiety and tension of a degenerating body politic upon the stage - the stage would have created a heterotopia in which they were thrust and forced to reflect upon the degenerating body politic in their own nation, and the fact that it too would, very soon, have to be "cured" by a successor.

Above all, the heterotopia is a grappling space. It is a space wherein anxieties can be encountered, examined, and eventually granted passage and transformed into solutions. The contained heterotopia of the stage, and the various heterotopiae presented 
within the play, urge community acceptance of the death of a long-standing political lineage and its replacement by an alternative, and vital, line from outside the realm. The heterotopic spaces within the play close when the body politic dies and Fortinbras assumes the throne. This vision urges the audience to do the same as the Danish - to accept the end of the long-deteriorating Tudor line, and to welcome the succession of a healthier bloodline. 


\section{CHAPTER II}

\section{A Merry Ghost, a Very Merry Ghost}

In the words of Ellen Meiksins Wood, "the most common way of explaining the origin of capitalism is to presuppose that its development is the natural outcome of human practices almost as old as the species itself...it appears as a resumption of a historical process that was temporarily- if drastically and for a rather long time deflected" (11-15). Derailment or not, feudalism had been the norm for centuries, and shifts seen in early modern England, such as increasing divisions of labor and specialization by trade networks, in addition to improved productive techniques - all designed to cut cost and enhance commercial profit - were dramatically different from previous decades - even centuries. The shift provoked anxiety on the part of the people, whether they were nobles or members of the middle and lower classes. In fact, Eric Hobsbawm calls the economic changes of the $16^{\text {th }}$ and $17^{\text {th }}$ centuries the "General Crisis" - that the unrest and anxieties of the century "was a symptom of a decisive phase in the transition from feudalism to capitalism" (Sharpe 4). For Meiksins Wood, England's translation into a truly capitalist nation began at the end of the $16^{\text {th }}$ century, when "an instant transition from feudalism to capitalism" (153) was incurred by the Tudor state's aggressive attempt to subdue the rebellious Irish via extra-economic control, which they did by "attempt[ing] to impose a kind of economic hegemony, using military force to implant a new economic system, as well as a new political and legal order" (153). The English government sought to establish this control by creating relations of tenant and landlord on Irish soil. The main goal of this project was to overpower Irish rebellion, but 
Ireland's “integrat[ion] into England's economic orbit and subject[ion] to its economic coercions" (154) would have made an attractive corollary.

The "aggressive colonialism" mentioned by Meiskins-Wood caused England to transform socially. The merchant classes grew, and upward class mobility became a reality for a great many people. This class mobility was a complete departure from earlier centuries. Thus, in addition to political instability, economic changes provoked by numerous shifts caused considerable anxiety for early modern citizens. The air of instability aggravated by these changes and shifts in economic structure were, as we saw with Hamlet, reflected in and through the stage.

\section{Like Hamlet, Frances Beaumont's The Knight of the Burning Pestle features a play} within a play. However, in the case of this often chaotic work, nearly all the plot circulates around this metatheatrical structure. To make matters more confusing still, Beaumont adds yet another layer to the bifurcated dramatic space - that is, the play within the play actually features yet another play of its own. While this enmeshedness might be considered a violation of the traditional dramatic structure, it allows for the formation of a heterotopia wherein the characters, players, and audience alike are forced to explore and make conclusions regarding both their being, and the world within which they interact daily. Once again, the presence of disease and the threats provided by the unhealthy body are present, and affect the messages transmitted within the space provided by the heterotopia; that is, the syphilitic body can only be acknowledged by the players and audience when they are removed from its immediate plane - it can only be discussed through the "safe" space of the heterotopia. Similar to what I suggested was at 
play within Hamlet, I argue that while disease and the language thereof are used in order to bring attention to a prevalent social ill, they are more probably referenced metaphorically. That is, when talking of syphilis, the characters within this "promiscuous city" comedy are countenancing and addressing a swiftly changing world and reality via this apt and readily understood analogy. It is my aim to show how, influenced by Hamlet, Beaumont elaborates upon the conceits found within Shakespeare's work, reforming them and twisting the structure of the play in order to point out not only the interactive triangle of germ, mechanism, and host, but also to remark by way of one fear obliquely upon another: changing capital structure, and how such changes could have effected British society at large. The action in this play (sometimes difficult to follow due to the constant scene interruptions and shifts) culminates in a battle between the dreaded Barbarosso (who forces syphilitic patients to undergo cruel and ineffective treatments) and Ralph, the grocers' apprentice and knight errant. In short, within this chapter I will assert and prove the ways in which Beaumont's infamous "flop" enforces a “play” space for Ralph, the Citizen, and his wife (and by osmosis, the audience) and creates a societal void, vacuum, or blank space. Certain scenes (themselves merely represented spaces) allow the characters to "play" at being what they are not societally, or be somewhere they are not, nor can ever hope to be. This practice of "make-believe" constitutes an experimental area wherein a changing world and changing financial structures are faced. It is the final climactic scene, referenced above, which dispels this alternative "play" space and forces the characters to close and resolve their posturing, and to make conclusions about the England in which they were living. 
Drama had undergone a number of great changes in the few years after Elizabeth I's death and James I's coronation in 1603 and 1604, respectively. In place of the classic Shakespearean tragedies and comedies of romance, the "city comedy" was often performed; this particular type of play centered upon the citizen, instead of the nobility. This genre of play was attractive to viewers, for it "offered a true to life presentation of London society and brought with it a new immediacy and freshness...furnishing an outlet for satiric descriptions of contemporary events.... Londoners could find in these plays a mirror of society" (Fabricius 168). The Knight of the Burning Pestle is a play of layers, and within the interstices of these layers, we can view reactions to changing contemporary life, ranging from topics as diverse as trade and promiscuity.

As early as the induction, the viewer's expectations are overturned. The speaker of the prologue introduces the play, (called 'The London Merchant') but before the players can proceed with the drama, this first dramatic layer is disturbed by a voice from the audience. Though the audience is led to believe that the voice in question belongs to one of their own, it is soon revealed to belong to a character in the play: the grocer, who complains that he cannot imagine how the players upon the stage could do justice to his most noble of professions: “...you have no good meaning: this seven years there hath been plays at this house, I have observed it, you have still girds at citizens; and now you call your play 'The London Merchant.' Down with your title, boy! Down with your title!" (Induction,10). The grocer's interruption is the first of many purposeful intrusions to the dramatic structure of the play. That is, less than four lines into the play, a second play has been added on top of it, or into it, creating a heterotopic space much like the 
addition of 'The Murder of Gonzago' to Hamlet. When the audience is introduced to the grocer (and soon after, his wife) they are asked to enter a reflective space wherein they are given a new vantage point: they are not being played at; rather, they are being played with, and being asked to participate, at least mentally, with the actions occurring upon the stage. That is, the audience is being asked to enter the reflective space of the heterotopia, and to make conclusions about the drama unfolding before their eyes.

After George (the grocer) and his wife, Nell, demand to be shown a play touting citizens, he further demands that his apprentice Ralph be given the starring role in this play. The speaker of the induction resists at first, reasoning quite correctly that the players cannot be expected to invent a play on such short notice, yet later relents, allowing for Ralph to insert his own ideas into 'The London Merchant.' And so, we see that a third layer is created atop the other two layers. Thus, the audience at the Blackfriars, the grocer and his wife, and Ralph all enter, at various times, into various different heterotopic spaces.

It is thus that both plays, "The London Merchant," and Ralph's play, called "The Knight of the Burning Pestle," begin together, within this dizzying multi-planar structure. The actors commence with their original play; which is the story of Luce and Jasper, who are barred from marriage by the young woman's father, Venturewell, a successful tradesman who, until he discovered their romance, was Jasper's employer. Though the similarities between Venturewell and George, as well as Jasper and Ralph, are obvious, their likeness does not create feelings of solidarity in the mind of the citizen; he and his wife soon disrupt this "first" play, making known their dislike for Jasper, calling him a 
"little infidel" (19) and demanding that their own apprentice, now in the guise of a noble knight, enter the action and commence with the drama which he has created. The dramatic layer that the citizen has ordered buffers he and his wife from their daily reality, and in so doing allows them to critique their own social class. Though the citizen expressed a strong desire to see his profession displayed nobly, he shows no interest in seeing the reality of his profession upon the stage. He instead calls for the creation of a picaresque romance. Clearly, George and Nell do not want to view the drama of Luce and Jasper, nor are they particularly interested in Venturewell; their only attachment to the drama in front of them is the parts where their apprentice Ralph might fit in, assuming the guise of a grocer-knight errant.

Perhaps even more so than her husband the citizen, Nell displays dislike and disapproval for members of her own socioeconomic bracket. Her discontent is evinced through her fawning treatment of the vapid Humphrey, to whom Venturewell has engaged his daughter, considering his higher social standing a better fit for Luce. She remarks to her husband "By my faith and troth, George, and as I am virtuous, it is e'en the kindest young man that ever trod on shoe-leather" (26). In reality, Humphrey is shallow and has a penchant for creating bawdy couplets; we must question why she so prefers him over Jasper, who like her adored Ralph is a young, struggling apprentice. While Nell's quickness to reject Jasper is indeed curious, the same sentiments are reflected within 'The London Merchant' by Venturewell himself. He eschews the marriage proposal of the young man he has trained for service, stating that he wants to make Jasper aware that he is "but a merchant's factor;" (Ii, 15) that is, he is little more 
than another one of the goods Venturewell buys and sells. Venturewell displays a hatred for his own profession in seeking to marry his daughter to a nobleman, or at the very least, a desire to distance her, and her offspring, from the marketplace. Humphrey, however, is furthermore deemed acceptable by Venturewell because of his buying power, though this very attribute would have provoked laughter from the audience of The Knight of the Burning Pestle proper. Consider Humphrey's method of courting Luce: from his pocket, he produces a pair of gloves, and says:

Look, Luce, look; the dog's tooth nor the dove's

Are not so white as these; and sweet they be,

And whipt about with silk, as you may see.

If you desire the price, shoot from your eye

A beam to this place, and you shall espy

$F S$, which is to say, my sweetest honey,

They cost me three and twopence, or no money" (I ii, 76-82).

Thus, it is a combination of buying power and Humphrey's nobility which make him a suitable match for Luce. Although Jasper might someday have money, it is doubtful that he would be elevated to the peerage. It is this social impossibility which makes him, in the eyes of Venturewell, an unfit husband. Both the citizen and Nell's agreement with Venturewell's disapproval of Jasper mirror the same drive to aspire to become what they are not, and will never be- nobility. The effect of Humphrey's manner of speech is, at least at this point in the play, little more than comic relief. He is the stock character of the brainless dandy, and the audience would have had a laugh at his expense although, for the audience of the Blackfriars, he would have been closer to their 
economic station than the grocer. As the layers of the play begin to interact more, however, Humphrey's effect becomes more vital - I will return to this point in a moment.

While it is true that Jasper is planning to abscond with his employer's daughter, I would venture a guess that most viewers would be sympathetic to the plight of the young lovers kept from one another. Nell, however, immediately states her disdain for Jasper and her admiration for Humphrey. Her preference, I believe, rests within the essential difference between the two young men: class. Jasper is a working man from a family without money, whereas Humphrey is, as he states, "of gentle blood and gentle seem" (20). Humphrey is nobility. Jasper is an apprentice - which would have made him more or less indentured - not a free man at all. Both reader and audience cannot help but notice that she is in effect critiquing her own social station, or attempting to erase the very system that afforded her and her husband their current station. Her own husband would have once been an apprentice, like Jasper. Within her critique of Jasper there rests a critique of apprenticeship, merchants, and any product bought and sold within the confines of her husband's profession.

Nell's disdain for her husband's profession, subtle though it may be, only continues. At the end of Act I, Scene Two, she makes the following proclamation regarding tobacco, a commodity commonly sold by grocers: "Fie, this stinking tobacco kills me! Would there were none in England! - Now, I pray, gentlemen, what good does this stinking tobacco do you? Nothing, I warrant you: make chimneys o' your faces!" Within this single remark, the citizen's wife obliquely criticizes both her husband's profession, and the newly founded colonies. Tobacco was grown in the Virginia and 
Maryland colonies, both of which were possessions of the crown during the run of this play in 1610. As a grocer, the citizen would have sold this product in his stores, and as it was a product in very high demand, the sale of this item would have, above all others, garnered them a fine profit. She shows an open hostility toward the very items from which her husband profited; as readers, we must extend that logic, and suggest that in so doing, Nell is showing disdain for his profession at large. And this she is only able to do because she is not a mere spectator of the play: she watches the action, but participates, and as such is able to synthesize her latent, hidden fears regarding the nature of their wealth gotten through these new structures of money-making. For both Nell and George, we see how "The London Merchant" is transformed into a reflective stage, upon which they permit themselves to voice their anxieties about the profession which supports them. Furthermore, this play space affords the citizen and his wife the chance to view how the rise in stature of the merchant classes is changing long-accepted social structures - and reveals their discomfort with the very upward mobility that has enabled their own rise.

The audience is soon introduced to Ralph, now assuming this role of nobility. He is dressed as a knight, but has added to his costume the customary blue apron of the grocer, conflating the roles of Knight and Grocer with this simple addition to his costume. As The Knight of the Burning Pestle, his goal is "to pursue this course, both for the credit of myself and our company," (I iii, 62-63) as he does not, "amongst all the worthy books of achievements...call to mind that [he] yet read of a grocer-errant" (6365). Ralph adopts the persona of the knight in order to bring honor to all of London's 
grocers, but also to raise the status of the grocer, and to play at a societal role that he will never embody, at least in its classic form.

On the heels of this conflation between merchant and noble comes another conflation: the fusion of an emerging form of capitalism, and syphilis. Still wearing his blue apron, Ralph thanklessly bemoans a grocer's duties: “... what brave spirit would be content to sit in his shop, with a flappet of wood, and a blue apron before him, selling mithridatum and dragon's water to visited houses, that might pursue feats of arms, and, through his noble achievements, procure such a famous history to be written of his heroic prowess?" (52-58). In effect, the "knight" is not only expressing his desire to lead another, more noble sort of life, but he is also intimating that one of the functions of a grocer is to sell "cures" for the prevalent affliction of syphilis, thus joining the sale of such items to the propagation of the illness itself. Mithridatum, also known as theriac, was a toxic brew of sundry poisons (sometimes up to 300 , depending on the creating chemist) which was believed to be a panacea against pests, witchcraft, and even syphilis. By 1610, however, theriac would have been largely out of use. Ralph's reference indicates his disdain for the wares sold by those in his profession, yet it furthermore implies that the man of trade is at odds with the man of nobility: where one is content to sell antiquated treatments for a shameful affliction, mostly to "visited houses," (brothels) the other feels compelled, spurred on by some higher authority, to embark on quests to "relieve damsels," and bring honor to the grocers of the world. Beaumont is obliquely suggesting that the marketplace caters to the rise of disease, as grocers and others in similar positions of sale are responsible for selling the products used for its management, 
and furthermore, that the marketplace contributes to societal decay. Metaphorically speaking, the marketplace is disease: take, for example, the panacea mithridatum. Merchants of such cures were aware that they were ineffective at best, yet still preyed upon the gullibility of the infected to sell their product. Still transmitting infection regardless of the "cure," the disease only spread. So too operates the marketplace: as England expanded her operations to include and benefit from the vast raw wealth of the colonies, that disease would only spread and infect other populations. How ironic, then, that the grocer responds to Ralph's comment by stating "Some more of these words!" (29). It seems that not only his wife is uneasy with the transformation of the marketplace. Though the citizen expresses pride for his profession, he echoes Ralph's unease at engaging in a trade which may be damaging to the fiber of English society.

It is on this note that Ralph, clad in his blue apron, begins his transformation into the Knight of the Burning Pestle, "in remembrance of [his] former trade." The allusion behind his new name cannot have been lost on the audience, nor are they lost on the present day reader. Particularly ribald is the suggestion that the grocer's trade be represented by a "burning pestle." A grocer, then, is pictorially represented by a diseased phallus. Again, we see the equivalence of merchant and trade with disease. Furthermore, inasmuch as the purpose of a shield (besides the obvious protective one) was recognition by both the public and enemies, it seems others would have made this connection as well - the bearer of the shield would have wanted that connection to be made. Ralph implies, and not at all obliquely, that his "former trade" should be understood via symbols such as 
the male sexual organ, crippled by syphilis. That is, that grocers in general have become diseased by capitalism and the greed inherent to this growing commercial model.

Ralph continues to assume the manners of nobility, decreeing, "from henceforth you never call me by any other name but 'the right courteous and valiant Knight of the Burning Pestle;' and that you never call any female by the name of a woman or wench, but 'fair lady,' if she has her desires, if not, 'distressed damsel;' that you call all forests and heaths 'deserts' and all horses 'palfreys.' (30) We observe Ralph impose an alternate space over his own, so that he is able to simultaneously deny, yet come closer to navigating his own occupied space. In so doing, Ralph creates a third layer which he lays upon the second - it is his own, personal heterotopia, through which he synthesizes the realization that he, although he is only an apprentice to a grocer, is a part of swiftly altering capital structures; indeed, the entire market system of England as they knew it is thus entailed.

Ralph's class posturing is misunderstood by the grocer and his wife. They continue to think him simply "very fine." Thus, we see not only how the first dramatic layer is disrupted by the second, but also how George and Nell create a personal protective space which serves to buffer them from the very real implications wrought by "The London Merchant." The space that they create is shared by the audience, who, because of their interruptions to the original play that they see in front of them, are asked to participate actively and critically with the entire drama - to follow Nell, George, and Ralph's lead, as it were. As these additional characters punctuate the stage with their 
disapproval of commerce, despite their daily interaction with it, the audience is permitted to do the same.

Ralph's first interruption sets a precedent for the rest of the play. Throughout the acts, the love story between Jasper and Luce is continually punctuated by the "pestle," as it were; that is, Ralph, accompanied by his squire and page, repeatedly interrupts "The London Merchant" with his aimless quest. Beaumont's illusion is a dual one. Of course, if the reader conceives of the "pestle" as a stand-in for syphilitic infection, Ralph's constant interruptions of the other storyline seem to hint towards the overwhelming presence of disease in each and every storyline in existence - the story of love, the story of the bumbling, foolish suitor, the story of Mistress Merrythought and her hapless son Michael. The pestle interrupts each action and interaction, proving the inescapability of the disease. It was a ubiquitous scourge, never far from the mind of the public.

Furthermore, if we conceive of the pestle as indicative of new forms of commerce "diseasing" the nation, we realize that Ralph's reflective space is opening up an entirely new and separate area of reflection for the audience. They are forced to reflect not only upon the presence of disease in their midsts, and the force with which it has wracked through their lives, but they are also forced to realize the strength and utter tenacity of capitalism, an entity which was just originating at this very moment in history. Capitalism, though it may not have been called such at this time, was given the very same symbol as a disease which had plagued Europe for the past century.

Ralph's, and thus the pestle's, actions in Act II Scene ii overlay the drama of Mistress Merrythought and her son Michael, Jasper's younger brother, who have left her 
hedonistic husband and seek their fortunes elsewhere. While the characters from the opposite stories do meet, they somehow do not meet within the same setting, strange though it may seem. While Mistress Merrythought and Michael are traveling through regular old Waltham Forest, Ralph and his squires have been transported to a wholly different landscape - the "perilous Waltham-down..." (45). When met by The Knight of the Burning Pestle, she is frightened, runs, and drops her basket of jewels. Henceforth, she has played the part of a shrew, yet in Ralph's dramatic space, she becomes a "distressed damsel" and "fair lady." The convergence of planes and the transformation of characters we see in this episode, coupled with the resulting confusion regarding identity, again signal a grappling with societal position through enforcing a separate identity upon others. Mistress Merrythought's change is not significant to her - she does not seem to be at all aware of her elevated status - which is, of course, only part and parcel of the hilarity which ensues. However, the ease with which the shrewish, complaining Mistress Merrythought speedily turns into a distressed damsel, is indicative, once again, of Rafe's disavowal to see the reality of the changing social moment within which he is rooted.

Ralph, who as a grocer would have been concerned with money, and making money, is able to depart from the role of young merchant through this sort of play acting and make-believe. In this scene, he again deflects his identity, and retreats to the comforting play space afforded him by the heterotopia created by both the structure of the play, and the stage itself. Ralph's fantasies are exemplified by the conversation between the tapster (to whom Ralph insists on referring as Squire Tapstero) and "the knight" at the Bell Inn 
in Waltham (henceforth referred to as the holy Bell). Ralph approaches the publican, stating,

"Right courteous knight, who, for the order's sake Which thou hast ta'en, hang'st out the holy Bell, As I this flaming Pestle bear about, We render thanks to your puissant self, Your beauteous lady, and your gentle squires For thus refreshing of our wearied limbs, Stiffening with hard achievements in wild desert."

The audience and reader sees, after Ralph makes these statements, that others do not perceive him in the same light as he does - his courtliness, nobility - they are both little more than imaginings, for the Tapstero responds: "Sir, there is 12 shillings to pay" (76). The tapster remains firmly entrenched in a reality which is driven purely by the marketplace, continually demanding he be paid his 12 shillings, while Ralph continually reminds him that he is on a noble quest, offering knighthood to any of his "squires" who will accompany him on his adventures. And while the hostler does play along with Ralph, matching his outdated style of language, he still demands payment. When payment is not remanded, it seems certain that the two will come to blows -but the Citizen steps in, and provides the tapster with the payment he has been asking for. Here, we see the first proof of the power of coin over nobility. While Ralph might be a knight, his posturings are not able to save him from a barroom brawl over the paltry matter of ten shillings, whereas the citizen shows his true power - his money. Though he is fascinated 
with Ralph's courtly drama, he only knows how to operate as if he were in the marketplace, diffusing his apprentice's problems with a quickly paid sum of coin.

It is within this same scene that Beaumont ties together the previously separate issues of space and syphilis. Once Ralph's debt has been charged off, the Hostler informs him of the giant Barbarossa, whom he describes thus:

"He shakes a naked lance of purest steel, With sleeves turned up; and him before he wears A motley garment, to preserve his clothes

From blood of those knights which he massacres

And ladies gent: without his door doth hang

A copper basin on a prickant spear;

... and underneath his chin

He plants a brazen piece of mighty bord...

Whilst with his fingers, and an instrument

With which he snaps his hair off....

Every knight-adventurer he doth trim,

And now no creature dares encounter him" (81).

The hostler is describing nothing more uncommon than a barber surgeon. Though these "medical" professionals were ordinary, they were feared for their inexpert treatment of wounds and afflictions, particularly syphilis, which many well-respected physicians refused to treat. This association would have been recognized by the audience. Similar to the manner in which Ralph has turned Waltham forest into a savage desert, he turns a commonplace journeyman into a "huge giant," undertaking the slaying of Barbarossa as his next quest. 
Within the heterotopia of the stage, a simple barber shop in Waltham becomes the lair of a fearsome giant. Ralph's posturing enables the Citizen and his wife, in addition to the audience of the play, to enter another constructed space, one meant to assist with the synthesis of understanding and grappling with "disease," here a metaphor for changing capital structures. The introduction of Barbarossa to Ralph's quest, while it initially seems disruptive, actually lends more structure and sense to the chaotic storylinethat is, if the reader is willing to engage in a bit of close study and analysis. Ralph, in his costume of the knight errant of diseased capitalism, travels to Barbarossa's lair, in order to wage war with he who tries to cure the pains of syphilis. After wounding Barbarossa, Ralph begins to free his prisoners - first, "a Man winking, with a basin under his chin." The allusion being made here is that Barbarossa was attempting to cure the Man with the Mercury treatment, which was known to cause excessive salivation. After a few rounds of treatment, salivation would be so severe that the diseased might have to wear this type of bucket under the chin in order to catch the excess moisture. The man explains that Barbarossa has locked him in his lair in order to cure him, evidently with the mercury treatment, of syphilis. Ralph's squire soon leads another of Barbarossa's "victims" out of his lair. This one is described as "a second man, with a patch over his eye." The allusions to syphilis could not be any clearer. One of the most frightful symptoms of tertiary syphilis is the gumma, a granuloma of inflamed necrotic tissue that forms inside of the sufferers' bones, eventually causing them to collapse. The gumma often grows in the bones of the extremities, such as the hands, feet, or protruding facial bones. The "second man" has apparently grown a gumma on his nose, which has eaten away at the 
bone, causing its structure to collapse. He now hides the empty space with a patch. $\mathrm{He}$ explains:

"I am a knight, Sir Pockhole is my name

And by my birth I am a Londoner

Free by my copy, but my ancestors

Were Frenchmen all; and riding hard this way

Upon a trotting horse, my bones did ache;

And I, faint knight, to ease my weary limbs,

Light at this cave; when straight this furious fiend,

With sharpest instrument of purest steel,

Did cut the gristle of my nose away,

And in the place this velvet plaster stands:

Relieve me, gentle knight, out of his hands! (III iv 88-100)

Barbarossa's second "victim" is more telling than the first. The audience would know that he is infected with syphilis and no other ailment because of the language used. He unabashedly introduces himself as "Sir Pockhole;" obviously, this is a direct reference to the common name of syphilis - the pox. The individual papules of the "copper penny" rash particular to syphilis were called pocks - when they healed, they left small scars shaped like holes, fittingly called "pockholes." Sir Pockhole explains that by ancestry he is French- another telling clue as to his affliction. Syphilis was, as I explained previously, often called the "French Disease," and it was thought that French armies had introduced it to England. He continues, describing the most well-known symptom of syphilis: the aching bones caused by the formation of gummatous tissue. Once a gumma had over taken an area of the body, a physician or barber surgeon would attempt removal 
of the necrotic tissue, a procedure which Sir Pockhole describes as done by Barbarossa ("did cut the gristle of my nose away"). Sir Pockhole begs the Knight of the Burning Pestle to relieve him from the hands of the man attempting to cure him of his affliction. Considering the barbaric nature of these "cures," his plea might not sound odd to a present day audience, but in 1610, these were the only cures known for syphilis. Kinder, gentler forms of treatment would not be created until the discovery of penicillin in the $20^{\text {th }}$ Century. What seems an unforgivable cruelty today was then commonplace. Thus, it is alarming that Ralph's squire, the dwarf George, introduces Sir Pockhole as "another wretch, whom this foul beast/ hath scorched and scored in inhuman wise" (83-84). The enemy here is not syphilis; rather, it is the cure for syphilis and those in charge of the curing. It is the fault of Barbarossa, not Sir Pockhole or the other victim described before him, that these diseased men suffer as they do. It is not syphilis that creates the wretch, but the current inhumane cure.

The attitude surrounding syphilis only increases when Barbarossa's next "victims" are led from his cave. They tell the story of how they came to be held captive:

"I am an errant knight that followed arms

With spear and shield; and in my tender years

I was stricken with Cupid's fiery shaft, And fell in love with my lady dear, And stole her from her friends in Turnbull-street, And bore her up and down from town to town, Where we did eat and drink, and music hear; Till at length at this unhappy town 
We did arrive, and coming to this cave,

This beast us caught, and put us in a tub,

Where we this two months sweat..." (133-140)

We are again told the story of how the sufferer came to be afflicted with syphilis. Though Sir Pockhole became diseased merely by fault of his family's provenance, the third man (and the lady who accompanies him) clearly became among the afflicted by fault of unprotected sexual activity. The man describes the he "was [struck] with Cupid's fiery shaft;" which we must understand not as one of Cupid's arrows of love, but as the burning sensation of the male sexual organ in the first stages of infection by syphilis. $\mathrm{He}$ then fell in love with his lady dear, stole her from Turnbull-street, (known at this time for trade in sexual favors) and they traveled from town to town, carousing and spreading their shared affliction to all those they came in contact with. Oddly, it is not the couple who is called "beastly," but Barbarossa, who has locked them up in his cave, (preventing further spread of infection) and attempted to cure them with the sweating tub. The healer has become the giant, dreaded beast, and the syphilitic patient has become regarded as pitiable, and almost not at fault for their infection. No moral judgments are passed, and there are no words of shame spoken. The shameful has become the accepted.

Ralph's defeat of Barbarossa does not result in a curing of syphilis; rather, it results in the triumph of syphilis over any viable cure available at this time period. Disease emerges victorious. Shortly after Barbarossa's defeat, Ralph ceases his quest, and returns to "London" proper - he no longer travels to far -off lands upon the stage, but instead remains rooted in his everyday community. It is not coincidental that also shortly afterward, the Citizen and his wife cease their "play" as well - they no longer aspire to 
the nobility, and instead reveal their humble origins. At the end of Act III, the citizen and his wife no longer veil their origins, or express any desire to be anything other than their own social class. The acceptance of disease shown outside of Barbarossa's lair has affected them utterly: they call for beer, tumblers, soothsayers - all more low-brow enjoyments than the higher class audience at the Blackfriars would have been accustomed to. The tone of the play, most particularly the treatment of the citizen and Nell, turns at this time. Until this point, the audience would have had a laugh at their expense- their crude ways of speech and mannerisms, their inability to understand the plot of "The London Merchant" and insistence on staging their own, separate drama - but in the blink of an eye, it is they who are offering to buy the audience beer. Not only are they choosing a lower-class, tavern staple to foist upon their "guests," but they are also, and more importantly, the ones with the power of coin. They have the capability to buy a round of drinks for the theater, so financially stable are they.

Ralph also emerges triumphant from his "battle" with Barbarossa. He has not only defeated the "cure" of syphilis - he has defeated what "ails" capitalism. In accepting the presence of disease, and realizing that little can be done to stop its passage through the body, he sends the message to all in attendance that the progress of disease, much like capitalism, cannot be stopped. Ralph, now having passed through the transformative space of Barbarossa's dungeon, can say he is both a grocer's apprentice and a knight; indeed, he can be both. Having observed the entire action and interaction between the various spaces of the play, the citizen and wife are able to better understand their societal places as well, and the reality that they are a part of a newly- forming class 
of society: the merchant class. This point is only heightened when Nell says, "George, let Ralph travel over great hills, and let him be very weary, and come to the King of Cracovia's house, covered with black velvet; and there let the King's daughter stand in her window, all in beaten gold, combing her golden locks with a comb of ivory; and let her spy Ralph, and fall in love with him, and come down to him, and carry him into her father's house" (36-45). Not only does Nell, the wife of a grocer, have the power to direct the action of the play, but she also has the power to demand that a princess nearly made of gold fall in love with a grocer's apprentice. Ralph, however, is comfortable in his new role of grocer and knight, and refuses the princess' offer, saying:

I have a lady of my very own, In merry England, for whose virtuous sake I took these arms And Susan is her name, A cobbler's maid in Milk Street; whom I vow Ne'er to forsake while life and pestle last' (42-46)

Susan, the cobbler's maid, is enough for Ralph. He is not ashamed of his position any longer, and does not feel the need to posture towards a higher social standing. The entire exchange shows that the merchant class is the new nobility, and through the entrance into the heterotopic space of the stage, Ralph evinces this fact to the audience.

He does this even more so in the final act of the play. The citizen's wife directs him, saying:

Ralph, I would have thee call all the youths together in battle ray, with drums, and guns, and flags, and march to Mile-End in pompous fashion, and then exhort your soldiers to be merry and wise, and to keep their beards from burning, Ralph; and then 
skirmish, and let your flags fly, and cry, 'Kill, kill kill!' Do it bravely, Ralph, and think before whom you perform and what person you represent."

Ralph is directed to let the banner of the grocer fly high for all and sundry to see, and told to comport himself well, as befits a grocer - not a knight. As they march, Ralph directs "his" men:

"Gentlemen, countrymen, friends, and my fellow-soldiers, I have brought you this day, from the shops of security and the counters of content, to measure out in these furious fields honour by the ell, and prowess by the pound....I have no more to say but this: stand to your tacklings, lads, and show to the world you can as well brandish a sword as shake an apron."

The above speech shows the extent to which the apprentice/ knight errant has discovered (through the heterotopia provided by the play's structure) that when he assumes the mantle of the Knight of the Burning Pestle he is not only pretending. After his confrontation with the dreaded Barbarossa, Ralph accepts his career; indeed, he is proud of it, as he now realizes that it is not so ignoble as he had first thought.

Ralph's uncontainable presence across each and every layer of the play proves the equally uncontainable nature of syphilis, and the construct which syphilis represents: capitalism. Ralph's magnificent journey throughout the play is curative, though it may not cure the germ that we'd expect. That is, syphilis, or capitalism is not banished - that construct is accepted - it is the anxiety surrounding the changes wrought by increased trade and the new commercial structure forming as a result of such increases that is banished. Instead of bringing the breakdown of society, the Burning Pestle brings community and laughter - a knitting together of societal fabric - not a destruction of a court, as we saw in Hamlet. The message is clear: changes may be coming, but there is 
little we can do about them - we must have laughter. At the plays closing, Merrythought sings:

Better music was never known

Than a quire of hearts in one.

Let each other, that hath been

Troubled with the gall or spleen,

Learn of us to keep his brow

Smooth and plain, as ours are now:

Sing, though before the hour of dying;

He shall rise, and then be crying,

'Hey, ho, 'tis naught but mirth

That keeps the body from the earth!"”

Merrythought's song was meant to resonate with the audience, who were meant to take heed of the lessons taught by the play before them. They were meant to see that the economic shifts and resultant anxieties so plaguing England at this time were momentary - that they must accept these changes, and laugh. George and Nell close the play reminding the audience that they are, at least fiscally, now powerful citizens. Nell says, when her husband asks her if they should leave the theater: "Nay, by my faith, George, I have more manners than so; I'll speak to these gentlemen first. I thank you all, gentlemen, for your patience and countenance to Ralph, a poor, fatherless child; and if I might see you at my house...I would have a bottle of wine and a pipe of tobacco for you..." Nell is able, and willing, to extend an invitation to the audience to come to her home, and benefit from her hospitality. Clearly, the times are changing, and Beaumont is urging the audience to, simply, take what the grocer can offer, and be content. 


\section{CLOSING}

If not for both Shakespeare and the duo of Beaumont and Fletcher's use of space in these two plays, the audience would not have forged such a strong connection between the play and their lives both individual and as part of a societal framework that was at this time undergoing a barrage of changes and shifts. In examining the use of space in these two plays, we see evidence that temporal thinking had not quite taken the place of the spatial, but we also see a marked difference in how and what the audience encounters in the space provided. Here, I do not necessarily mean the encounters with the two "bodies" in question: I mean how space is dealt with by the actors in these plays, and how their manner of "dealing" would have affected each audience.

In Hamlet, the space opened up by the isolated presence of syphilis follows the form of the disease itself - it is isolated to select bodies, yet threatens to become an epidemic. Heterotopia is singular, personal: only one character enters his own, and grapples with his body in his own little space. This compartmentalization of body failure suggests the possibility of a cure: if the disease has not spread to infect all "layers" of the play at once, perhaps the body can be saved. While the individual infected human bodies eventually fail, the larger state body is remedied by the arrival of a new monarch from another, cleaner land. Shakespeare's message to his audience is clear: accept a new ruler, and heal Britain. Then, our current society will be "cured," or will be permitted to continue as normal.

The Knight of the Burning Pestle, however, presents a much less compartmentalized version of the heterotopia, which seems to suggest the "incurability" of, in this particular 
case, capitalism. While the message sent to the audience in this play also urges acceptance of societal shifts, the play's structure (or lack thereof) suggests the incontainability of capitalism, in addition to the social and economic changes it wrought. The message, then, is not merely to accept change in order to stay the same; rather, it is to accept change in order to progress into a new era. 
Works Cited

Beaumont, Francis and John Fletcher. The Knight of the Burning Pestle. Ed. Colin Counsell. London: Nick Hern Books, 2001. Print.

Bergeron, David M. "Paratexts in Francis Beaumont's The Knight of the Burning Pestle." Studies in Philology. 106.4 (2009): 456-467. Print.

De Certeau, Michel. The Practice of Everyday Life. Berkeley: University of California Press, 1988. Print.

Fabricius, Johannes. Syphilis in Shakespeare's England. London: Kingsley Press, 1994. Print.

Foucault, Michel. "Of Other Spaces, Heterotopias." Architecture, Mouvement, Continuité 5 (1984): 46- 49. Print.

Fracostoro, Girolamo. De contagion et contagiosis morbis (translated by W. C. Wright). New York: Putnam, 1930. Print.

Harvey, David. The Condition of Post Modernity: An Enquiry into the Origins of Cultural Change. Oxford: Blackwell, 1990.

Harris, Jonathan Gil. Sick Economies: Drama, Mercantilism, and Disease in Shakespeare's England. Philadelphia: University of Pennsylvania Press, 2004. Print.

Hobsbawm, E.J. The General Crisis of the Seventeenth Century, in Trevor Aston (ed) Crisis in Europe 1550-1660 (1965) p. 53.

Hoeniger, David. Medicine and Shakespeare in the English Renaissance. Newark: University of Delaware Press, 1991. Print.

Hughes, Ann. Seventeenth-century England: A Changing Culture. London: Pentos, 1980. Print.

Kinney, Arthur F. Elizabethan Backgrounds: Historical Documents of the Age of Elizabeth I. Hamden, Connecticut: Archon Books, 1975. Print.

Lindemann, Mary. Medicine and Society in Early Modern Europe. Cambridge: Cambridge University Press, 2010.

Lowe, Peter. An Easie, Certain, and Perfect Method, to Cure and Prevent the Spanish Sicknes. London: 1596.

Lucasz, Stanek. Henri Lefebvre on Space: Architecture, Urban Research, and the Production of Space. Minneapolis: University of Minnesota Press, 2011. Print. 
Meiksins Wood, Ellen. The Origin of Capitalism: A Longer View. London: Verso, 2002. Print.

More, Thomas, ed. Dominic Baker - Smith. Utopia. London: Penguin, 2012. Print.

Quétel, Claude. The History of Syphilis. Trans. Judith Braddock and Brian Pike. London: Polity Press, 1990. Print

Shakespeare, William. Hamlet. Ed. Susanne L. Wofford. Boston: Bedford/ St. Martin's, 1994. Print.

Sharpe, J. A. Early Modern England: A Social History 1550-1760. London: Arnold Publishing, 1997. Print.

Smith, Joshua S. "Reading Between the Acts: Satire and Interludes in The Knight of the Burning Pestle. Studies in Philology 109.4 (2012): 474-495. Print.

Soja, Edward W. Postmodern Geographies: The Reassertion of Space in Critical Theory. London: Verso, 1989. Print.

Tuan, Yi-Fu. Topophilia: A Study of Environmental Perception, Attitudes, and Values. London: Prentice-Hall International, 1974. Print.

Waith, Eugene. Patterns of Tragicomedy in Beaumont and Fletcher. New Haven: Yale University Press, 1969. Print. 